\title{
DAMPAK PELABELAN RAMAH LINGKUNGAN (ECOLABELLING) PERIKANAN BAGI NELAYAN IKAN HIAS
}

\section{Impact of Fisheries Ecolabelling in Ornamental Fisher}

\author{
Humayra Secelia Muswar ${ }^{*}$ dan Arif Satria
}

Departemen Sains Komunikasi dan Pengembangan Masyarakat, Fakultas Ekologi Manusia, IPB

*) Email : humayramuswar@gmail.com

Diterima 20 Desember 2011 / Disetujui 23 November 2011

\begin{abstract}
Les village's fisher has specialized in catching ornamental fish since 1982 by using potassium cyanide, after years the coral reefs were severely damaged. Awareness of fisher emerged to change their fishing patterns became more environmentally friendly. In the beginning 2000, the green movement was initiated by the NGOs began to change the condition of Les' fisheries system. Balinese traditional society and the fisher awareness had a big role to control this protection road to the sustainable fisheries. In 2006, ecolabelling certification was introduced to Les' fisher. It was applied for two years (2006-2008). This study analyzised the influence of ecolabelling's socioeconomic to ornamental fish fisher.
\end{abstract}

Keywords: ornamental fisher, ecolabelling, sustainable fisheries, Bali, Indonesia.

\section{ABSTRAK}

Nelayan di Desa Les memiliki spesialisasi dalam menangkap ikan hias sejak tahun 1982 dengan menggunakan potasium sianida, setelah bertahun-tahun terumbu karang rusak parah. Kesadaran nelayan muncul untuk mengubah pola penangkapan ikan mereka menjadi lebih ramah lingkungan. Pada awal 2000, gerakan hijau ini diprakarsai oleh LSM mulai mengubah kondisi sistem perikanan Les. Masyarakat tradisional Bali dan kesadaran nelayan memiliki peran besar untuk mengontrol jalannya perlindungan terhadap perikanan berkelanjutan. Pada tahun 2006, sertifikasi ekolabel diperkenalkan kepada nelayan Desa Les. Itu diterapkan untuk dua tahun (2006-2008). Penelitian ini menganalisis pengaruh yang ekolabel sosial ekonomi bagi nelayan ikan hias.

Kata kunci: nelayan ikan hias, ekolabel, perikanan berkelanjutan, Bali, Indonesia.

\section{PENDAHULUAN}

Indonesia merupakan negara yang memiliki luas wilayah laut yang lebih besar dibanding dengan daratannya. Hal ini membuat perikanan menjadi salah satu sektor penentu perekonomian Indonesia. Oleh karena itu, UndangUndang Nomor 17 Tahun 2007 tentang Rencana Pembangunan Jangka Panjang Nasional memuat misi pembangunan jangka panjang yakni, "menjadikan Indonesia sebagai negara kepulauan yang maju kuat dan sejahtera" memberikan arah yang jelas dalam pem-bangunan nasional berbasis kelautan ${ }^{1}$.

Pada prakteknya penangkapan ikan di Indonesia tidak terlepas dari penangkapan yang berlebihan (overexploitated) dan penangakapan yang merusak (destructive fishing) baik degan alat maupun bahan yang digunakan untuk menangkap ikan. Terutama pada perikanan ikan hias, penangka-pan ikan hias cenderung merupakan

\footnotetext{
${ }^{1}$ Dikutip dari Tulisan Dasril Munir (Kepala Sekretariat Dewan Kelautan Indonesia) dalam Demersal edisi Desember 2010
}

penangkapan ikan yang merusak. Terlebih bahan yang digunakan nelayan adalah bahan kimia potasium-sianida yang dapat merusak terumbu karang. Sumatera Barat merupakan salah satu propinsi di Indonesia yang telah mengalami kerusakan lingkungan laut yang cukup parah akibat penggunaan sianida. Rusaknya terumbu karang yang merupakan habitat bagi biota laut laut lainnya turut menyumbang kepunahan beberapa spesies ikan hias. Hal ini juga hampir terjadi di beberapa propinsi di Indonesia, seperti Bali.

Kesadaran masyarakat internasional yang meningkat mengenai produk hasil ramah lingkungan menjadi awal munculnya istilah ecolabelling atau pelabelan ramah lingkungan (PRL). PRL muncul sebagai sebuah gerakan yang mendukung produksi yang ramah lingkungan dan berkelanjutan. PRL adalah label yang dicantumkan kepada produk yang telah berhasil memenuhi kriteria ramah lingkungan yang ditetapkan oleh lembaga sertifikasi. Sebelum PRL dibicarakan dalam ranah perikanan, PRL telah lebih dahulu diterapkan pada hasil produk 
kehutanan. Keberhasilan PRL dalam sektor hasil hutan menjadi pertimbangan dilaksanakannya PRL pada sektor perikanan.

Desa Les, Kecamatan Tejakula, Kabupaten Buleleng, Bali Utara merupakan wilayah penghasil ikan hias ramah lingkungan terbesar di Bali. Para nelayan ikan hias Desa Les telah mengalami perubahan mendasar pada cara penangkapan yang dilakukan. Nelayan pernah menjadi perusak karang selama satu dasawarsa untuk memenuhi permintaan ikan hias yang tinggi. Penggunaan potassiumsianida menjadi cara utama yang dilakukan nelayan untuk menangkap ikan hias. Dengan usaha penyadaran dari beberapa LSM, nelayan ikan hias Les mulai meninggalkan potasium-sianida dan beralih menggunakan cara tangkap yang ramah lingkungan. Sebagai wilayah best practiced penangkapan ramah lingkungan, MAC mensertifikasi sistem perikanan ikan hias di Desa Les. Mulai dari para nelayan ikan hias, pengepul, hingga eksportir disertifikasi untuk menghasilkan produk perikanan yang ramah lingkungan.

Menganalisa pola nafkah nelayan menjadi batu landasan dalam melihat bagaimana dampak sosial dan ekonomi nelayan terhadap praktek ekolabeling yang terjadi. Berangkat dari analisa itu kemudian akan diteliti penerimaan masyarakat nelayan terhadap program ini dan posisi nelayan dalam praktek perikanan ini. Terkait hal tersebut, bagaimana praktek perikanan ikan hias di Desa Les sebelum, saat, dan setelah pelaksanaan pelabelan ramah lingkungan (PRL) dan bagaimana dampak sosial, ekonomi, dan ekologis bagi perairan Desa Les adalah pertanyaan yang mewakili perumusan masalah pada penelitian ini. Penelitian ini memiliki manfaat antara lain:

1. bagi mahasiswa, yaitu memberikan tambahan pengetahuan kepada mahasiswa mengenai PRL perikanan yang dilaksanakan di Indonesia. Pada penelitian ini akan dilihat bagiamana PRL dari pendekatan ekologi politik dan pengelolaan kolaboratif sumber daya alam sehingga membuka realitas pikiran bagi mahasiswa dalam menanggapi permasalahan ini. Tulisan ini diharapkan dapat menjadi referensi dalam melakukan penelitian-penelitian selanjutnya, juga untuk memancing sisi kritis mahasiswa dalam bertindak menanggapi fenomena lingkungan yang terjadi;

2. bagi masyarakat, penelitian ini membantu kepada masyarakat khususnya masyarakat nelayan di Desa Les, Bali untuk mengetahui sejauh mana ekolabeling perikanan mempengaruhi kehidupan mereka. Penelitian ini diharapkan dapat membuka cakrawala pengetahuan masyarakat nelayan mengenai fenomena yang sedang terjadi. Diharapkan penelitian ini dapat mengembangkan pemikiran dan motivasi serta semangat masyarakat nelayan untuk tetap mendukung berjalanannya perikanan yang berkelanjutan;

3. bagi pemerintah, penelitian ini diharapkan dapat menjadi masukan dan bahan pertimbangan dalam menentukan kebijakan yang berkaitan dengan praktek perikanan yang berkelanjutan khususnya dengan penerapan PRL perikanan. Diharapkan pemerintah terkait agar memperhatikan kendala-kendala yang tengah dihadapi oleh masyarakat kecil, seperti nelayan. Penelitian ini diharapkan dapat membuka mata bagi para pemangku kekuasaan untuk melihat baik buruknya pelaksanaan PRL perikanan, sehingga dapat menyikapi fenomena dengan bijak dalam rangka mewujudkan perikanan yang berkelanjutan di Indonesia.

\section{PENDEKATAN TEORITIS}

Masyarakat nelayan menurut Satria (2002) digambarkan memiliki karakteristik tertentu yang cenderung berbeda dengan masyarakat lain yang tidak tinggal di daerah pesisir. Desa pesisir merupakan cerminan dari desa-pantai dan terisolasi yang memiliki karakteristik dalam beberapa aspek, diantaranya sistem pengetahuan, sistem kepercayaan, peran wanita, struktur sosial, dan posisi sosial nelayan. Sebagai negara kepulauan, laut merupakan wilayah terluas di Indonesia dibandingkan daratan. Sebagian besar masyarakat Indonesia tinggal di sepanjang garis pantai.

Desa pesisir menurut Satria (2009) dalam bukunya "Pesisir dan Laut Untuk Rakyat", merupakan tempat bertemunya entitas sosial ekonomi, sosial- budaya, sosialekologi, yang menjadi batas antara daratan dan lautan. Sementara masyarakat pesisir menurut Satria (2004) dalam Satria (2009), adalah sekumpulan masyarakat yang hidup bersama-sama mendiami wilayah pesisir membentuk dan memiliki kebudayaan yang khas yang terkait dengan ketergantungannya pada pemanfaatan sumber daya pesisir.

Interaksi masyarakat pesisir dan aktivitas pembangunan menurut Cicin-Sain and Knecht (1998) dalam Putra (2002) mengakibatkan kerusakan ekologi pada zona pesisir dan sumber daya pesisir. Ditambah dengan tingginya permintaan pasar dunia akan pasokan ikan dan disperitas harga ikan menyebabkan terancam gulung tikarnya sektor perikanan di sejumlah negara (Demersal edisi Desember 2010). Kedua hal di atas turut menyumbang peranan dalam semakin tergerusnya sumber daya pesisir.

Undang-Undang Nomor 9/1985 tentang Perikanan, Pasal 6 ayat 1 melarang penggunaan sianida untuk perikanan. Penggunaan sianida menjadi cara penangkapan yang populer karena cara ini dianggap cara paling mudah. Nelayan menyemprotkan larutan sianida dari botol plastik. Semprotan sianida akan membuat ikan pingsan sehingga mudah dibawa ke permukaan (Kartodiharjo, 2006). Ini merupakan salah satu contoh pola tangkap ikan hias yang tidak ramah lingkungan. Untuk itu diperlukan alternatif cara tangkap ikan hias, salah satunya dengan diversifikasi alat tangkap.

Diversifikasi alat tangkap dalam penerapannya melalui proses adopsi inovasi. Proses adopsi terjadi apabila individu belajar mengenai suatu inovasi (teknologi baru) 
dan mengalami perkembangan pada mentalnya. Menurut komite yang terdiri dari ahli sosiologi pedesaan, The North-Central Rural Sociology Subcommittee for The Study of Farm Practise, ada lima tahapan dalam proses adopsi inovasi.

Proses adopsi inovasi inilah yang kemudian menetukan proses partisipasi individu nelayan dalam PRL. Partisipasi didefinisikan sebagai proses aktif, inisiatif dikemukakan oleh masyarakat setempat sendiri, dengan dibimbing oleh cara berpikir mereka sendiri, dengan menggunakan sarana dan proses (lembaga dan mekanisme) yang dapat mereka kontrol secara efektif (Nasdian, 2006). Partisipasi masyarakat secara bertingkat sesuai dengan gradasi kekuasaan yang dapat dilihat dalam proses pengambilan keputusan (Arstein, 1969). Ada pun pola distribusi kekuasaan dan peran dominan pemangku kepentingan diterangkan sebagai berikut:

1. manipulatif, partisipasi pada anak tangga ini tidak memerlukan respon partisipan untuk terlibat banyak;

2. terapi, yakni terapi yang mulai melibatkan anggota komunitas lokal untuk memberikan jawaban atas pertanyaan yang diberikan, tetapi jawaban ini tidak berpengaruh terhadap kebijakan;

3. pemberitahuan, yakni kegiatan yang dilakukan oleh instansi penyelenggara program sekedar melakukan pemberitahuan searah (sosialisasi program);

4. konsultasi, yakni anggota komunitas diberikan pendampingan dan konsultasi dengan semua pihak terkait sehingga diikutsertakan dalam penentuan keputusan;

5. penentraman, pada tahap ini komunikasi telah berjalan dengan baik dan sudah ada negosiasi antara masyarakat dan penyelenggara program;

6. kerjasama, merupakan tahap partisipasi fungsional di mana semua pihak baik masyarakat dan para pemangku kepentingan lainnya, mewujudkan keputusan bersama, dengan duduk secara berdampingan;

7. pendelagasian wewenang, merupakan suatu bentuk partisipasi yang aktif di mana semua anggota komunitas melakukan perencanaan, implementasi, dan monitoring;

8. pengawasan oleh komunitas, dalam bentuk ini sudah terbentuk independensi dari monitoring oleh komunitas lokal.

Partisipasi masyarakat nelayan mendorong agar diterapkannya praktek perikanan yang ramah lingkungan (PRL) didefinisikan oleh beberapa ahli, yaitu PRL oleh Gardiner dan Visnawathan (2004) diartikan sebagai penyedia informasi bagi konsumen dengan memberi kesempatan kepada konsumen untuk menunjukkan perhatiannya terhadap ekologi maupun lingkungan melalui produk yang mereka pilih. Nunes dan Riyanto (2005) menyebutkan bahwa PRL mengarah kepada skema kebijakan yang dikarakterisasi oleh evaluasi suatu produk, atau karakteristik produk. Hal ini berlawanan dengan menspesifikasi produk secara khusus. Intinya untuk mengukur dan mengemukakan secara detail nilai sosial, ekologi, dan ekonomi yang menjadi atribut dari produk tersebut. FAO (2007) mendefinisikan PRL sebagai pemberian label pada produk dengan sukarela guna menyampaikan informasi produk kepada konsumen untuk menciptakan insentif berbasis pasar demi pengelolaan perikanan yang lebih baik.

European Council (2002) dalam Mungkung et al. (2006) menyatakan bahwa PRL merupakan sebuah pendekatan, digunakan secara luas dalam mengindustrialisasikan negara-negara sebagai jalan untuk mempromosikan produk yang berkelanjutan dengan cara yang saling melengkapi, yakni dengan meyediakan informasi bagi konsumen untuk memudahkan mereka memilih produk yang lebih ramah lingkungan atau dengan menggunakan "brenchmarking" untuk meningkatkan pengembangan produk. Dalam buku "Seafood Ecolabelling: Principles and Practise", Ward dan Phillpis (2009) menyatakan PRL merupakan sistem yang dibentuk berdasarkan insentif dari mekanisme pasar untuk mendorong produk yang memberitahukan bahwa diproduksi dengan memperhatikan keberlanjutan ekologi.

Merujuk kepada Gardiner dan Visnawathan (2004) PRL memiliki tiga skema yang secara garis besar mengklasifikasikan PRL dalam tiga kategori. Adapun kategori tersebut, antara lain:

1. skema PRL jenis pertama atau biasa disebut self declaration. Skema ini diterapkan oleh perusahaan berdasarkan pada standar produk yang mereka produksi sendiri. Biasanya diinformasikan melalui media periklanan;

2. skema PRL jenis kedua. Skema ini diterapkan oleh asosiasi industri untuk konsumen mereka. Para anggota asosiasi ini menetapkan kriteria sertifikasi sendiri, atau terkadang dibantu oleh ahli dari luar asosiasi mereka, seperti akademisi maupun organisasi lingkungan;

3. skema PRL jenis ketiga. Skema ini diterapkan oleh inisiator (publik maupun swasta) yang bebas dari produsen, distributor, maupun pedagang dari produk tersebut. Produk yang disuplai oleh organisasi atau sumbernya disertifikasi untuk menginformasikan kepada konsumen bahwa produk ini ramah lingkungan. Skema ini bertipe sama dengan lisensi.

PRL perikanan merupakan peristiwa masuknya instrumen pasar dalam menangani masalah ekologis. Dalam buku "Seafood Ecolabelling: Principles and Practise", Ward dan Phillpis (2009) menyatakan PRL merupakan sistem yang dibentuk berdasarkan insentif dari mekanisme pasar untuk mendorong produk yang memberitahukan bahwa diproduksi dengan memperhatikan keberlanjutan ekologi. Dampak yang diartikan dari benturan antara dua kepentingan itu pun masih kurang tepat karena yang tercermin dari benturan tersebut hanyalah kegiatan yang menimbulkan dampak negatif (Kristanto, 2004). 
Munculnya program PRL ini kemudian menimbulkan dampak, baik dari sisi sosial dan ekonomi masyarakat nelayan dan ekologis lingkungan (terutama laut). Per ubahan pendapatan, perubahan kondisi tempat tinggal, ragam sumber pandapatan, serta kepemilikan alat tangkap menjadi tolak ukur ekonomi nelayan. Sedangkan dari sisi sosial, kekuatan jejaring sosial (networking), stratifikasi masyarakat nelayan, sebaran wilayah tangkap, dan tingkat kepuasan kerja oleh nelayan menjadi parameternya. Sementara luas tutupan karang dan keberanekaragaman ikan hias di laut Les menjadi alat ukur akibat yang dihasilkan dari PRL ini. Berikut dampak ekologis yang terjadi akibat berlangsungnya praktek PRL perikanan:

1. tidak diperbolehkannya perikanan tangkap yang menggunakan alat tangkap yang merusak (destructive fishing), seperti bom ataupun zat kimia berbahaya (Sainsbury (2010) dan Gardiner dan Visnawathan (2004)). Sehingga wilayah perairan laut yang sebelumnya terkena dampak negatif akibat penangkapan yang menggunakan bahan peledak dan zat berbahaya, seperti potassium-sianida, khususnya terumbu karang, menjadi baik kembali;

2. keterbatasan kelimpahan ikan (stok ikan) dapat mulai dikendalikan (Sainsbury (2010) dan Visnawathan (2004)). Penerapan pengelolaan yang tepat dan penghitungan produktivitas ikan di perairan, permasalahan stok ikan yang mulai menipis dapat diatasi. Indikator dalam hal ini adalah jumlah stok ikan;

3. penangkapan ikan yang memperhatikan keanekaragaman hayati ikan, maksudnya penangkapan dengan mempertimbangakan kelimpahan dan keberadaannya dalam rantai makanan (Sainsbury, 2010). Ikan langka dan hampir punah tidak akan ditangkap untuk diperjualbelikan disini. Sehingga rantai makanan ekosistem ikan di laut tidak terganggu;

4. dengan tidak digunakannya zat-zat kimia berbahaya dalam sistem penangkapan ikan, membuat masyarakat pesisir di sekitar pantai berkurang kemungkinan terkontaminasi zat berbahaya.

Dampak sosial ekonomi praktek PRL perikanan ini tidak bisa dipungkiri terjadi pada masyarakat nelayan. Di bawah ini beberapa butir dampak sosial ekonomi yang terjadi dalam praktek PRL, yaitu:

1. ada hak-hak nelayan yang tereduksi, karena hanya berfokus pada hasil tetapi tidak memperhatikan sistem pengelolaan yang digunakan (Molyneaux, 2008);

2. sertifikasi perikanan dapat mendorong kesadaran dan peningkatan pemasaran produk perikanan, namun tidak untuk perikanan skala kecil. Biaya sertifikasi yang tinggi, dan keeksklusifan yang ditawarkan pemegang sertifikasi PRL membuat adanya kesenjangan ekonomi dalam masyarakat nelayan (Schimidt, 1998 dalam Gardiner dan Visnawathan, 2004).
Ditambahkan leh Molyneaux (2008), skema ekolabeling yang dikendalikan oleh perusahaan tujuan akan berbalik arah sehingga tidak dapat dipercaya bahwa skema MSC ini dapat menguntungkan nelayan skala kecil. Ada pasar yang hanya membeli ikan yang bersertifikat, me-ngunci pada status ikan yang berkelanjutan dan potensial. Kembali lagi ini menguatkan bahwa PRL seakan menutup akses nelayan kecil untuk memperdagangkan hasil tangkapannya di pasar Internasional;

3. akan terjadi ketimpangan harga di pasar (Gudmusson dan Wessel, 2000). Oleh karena harga ikan yang bersertifikasi dinilai lebih tinggi sehingga hasil tangkapan yang tidak bersertifikasi PRL lebih rendah di pasar. Hal ini membuat nelayan skala kecil mengalami kesulitan dalam ekonomi.

Merujuk kepada Undang-Undang Republik Indonesia Nomor 23 Tahun 1997 tentang Pengelolaan Lingkungan Hidup yang menyatakan bahwa pembangunan berwawasan lingkungan hidup adalah upaya sadar dan terencana yang memadukan lingkungan hidup, termasuk sumber daya, kedalam proses pembangunan untuk menjamin kemampuan, kesejahteraan, dan mutu hidup generasi saat ini.

Ditambahkan FAO dalam Sinclair dan Valdimarsson (2003), perikanan berkelanjutan semestinya dilihat secara pendekatan holistik dan integratif juga dengan partisipasi dari para pemangku kepentingan yang mengarah kepada dimensi pengelolaan yang terpusat. Adapun hipotesis dalam penelitian ini antara lain:

1. terdapat hubungan perubahan pola kehidupan sosioekonomi masyarakat nelayan ikan hias akibat pelaksanaan PRL. Perubahan sosial yang terjadi memiliki hubungan:

- responden yang memiliki tingkat pendidikan yang tinggi cenderung memiliki keikutsertaan yang tinggi dalam kelompok,

- responden yang memiliki tingkat pengalaman kerja yang tinggi maka cenderung memiliki tingkat keikutsertaan yang tinggi,

- responden dengan tingkat pengalaman yang tinggi maka cenderung memiliki tingkat pendapatan tinggi,

- responden yang memiliki tingkat pengalaman kerja yang tinggi maka cenderung memiliki tingkat pendapatan yang tinggi;

2. terdapat perubahan ekologi perairan Les akibat pelaksanaan PRL;

3. terdapat perubahan pelaksanaan perikanan ikan hias setelah pelakaksanaan sertifikasi PRL. 


\section{KERANGKA PEMIKIRAN}

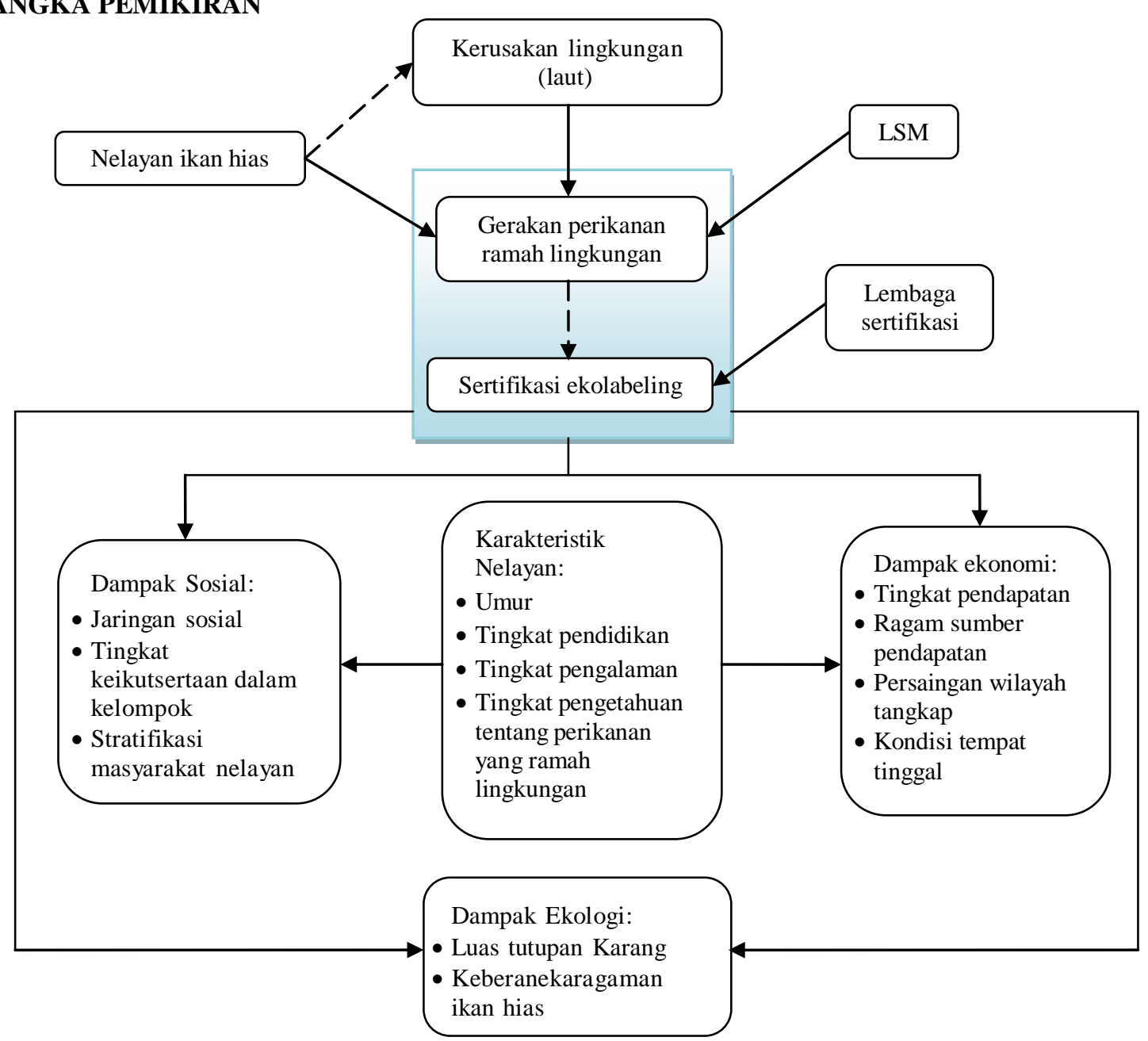

Keterangan:

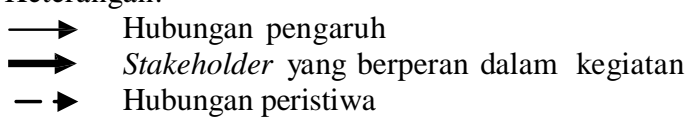

Gambar 1. Bagan Alir Kerangka Pemikiran Penelitian Sertifikasi Ekolabeling Dan Dampaknya Terhadap Nelayan Ikan Hias

\section{PENDEKATAN LAPANGAN}

Penelitian ini dilakukan di Desa Les, Kecamatan Tejakula, Kabupaten Buleleng, Bali. Sejalan dengan judul serta tujuan dari penelitian ini, melihat praktek pelabelan ramah lingkungan (ecolabelling) berlangsung dan bagaimana pengaruhnya bagi nelayan ikan hias. Lokasi ini dipilih secara sengaja karena latar belakang praktek perikanan ikan hias yang ramah lingkungan telah dilaksanakan di desa ini. Selain itu, karena para nelayan Desa Les ini sudah pernah tersertifikasi oleh lembaga sertifikasi "Marine Aquarium Council". Waktu penelitian dilakukan selama bulan Juni hingga Juli 2011. Metode dalam penelitian ini menggunakan pendekatan kualitatif yang didukung oleh pendekatan kuantitatif. Dalam metode penelitian kualitatif digunakan observasi, pengamatan, dan wawancara, sedangkan pada pendekatan kuantitatif, penelitian ini menggunakan metode penelitian survei. Penelitian survei adalah penelitian dengan mengumpulkan informasi dari suatu sampel dengan menanyakan melalui angket atau interview supaya menggambarkan berbagai aspek dari populasi (Fraenkel dan Wallen sebagaimana dikutip Wahyuni dan Muljono 2009). Penelitian survei yang dilakukan antara lain untuk melihat hubungan antara tingkat pendidikan nelayan dengan tingkat pendapatan dan tingkat keikutsertaannya dalam kelompok nelayan. Lalu melihat hubungan tingkat pengalaman kerja dan hubungannya dengan tingkat pendapatan dan tingkat keikutsertaannya dalam kelompok nelayan.

Pengambilan data dilakukan melalui dua tahap. Tahap pertama adalah pengambilan data melalui kuesioner yang dibagikan kepada responden dan informan untuk melakukan test sebagai preliminary research. Kemudian setelah dilakukan tes dilakukan pengeditan kuesioner sebagai 
kuesioner penelitian sesungguhnya yang disesuaikan dengan karakteristik masyarakat dan daerah lokasi penelitian. Hal ini dilakukan agar data yang diperoleh dapat terjamin, baik realibilitas maupun validitasnya. Oleh karena penelitian ini merupakan penelitian kualitatif yang didukung oleh kuantitatif, maka tahap kedua pengambilan data dilakukan dengan wawancara mendalam kepada beberapa pemegang peran serta pengamatan lapang. Selain itu diskusi kelompok terarah (Focus Group Discussion) dilakukan bersama para nelayan untuk memetakan permasalahan serta dampak yang terjadi. Diskusi ini menghasilkan gambar runtututan aktivitas perikanan yang terjadi di desa ini dalam kurun waktu 25 tahun dan diagram tulang ikan atas dampak yang terjadi dari aktivitas perikanan.

Jenis data yang akan digunakan dalam penelitian ini adalah data primer dan data sekunder. Data primer diperoleh melalui wawancara langsung, observasi lapang dan menggunakan kuesioner yang disebarkan, kemudian diisi oleh responden. Sedangkan data sekunder diperoleh melalui dokumentasi dan studi literatur yang berkaitan dengan tujuan penelitian, seperti buku, data potensi desa dan lainnya. Terdapat dua subjek penelitian yang terdiri dari informan dan responden. Informan adalah pihakpihak yang berpotensi untuk memberikan informasi mengenai diri sendiri, keluarga, pihak lain, dan lingkungannya. Pemilihan informan dilakukan dengan teknik snowball sampling (teknik bola salju). Teknik ini juga digunakan untuk menentukan daftar populasi yang karakteristiknya sesuai dengan masalah yang akan diteliti (kerangka sampling). Pada penelitian ini yang menjadi informan antara lain, Kepala Desa Les, Ketua Kelompok Nelayan Ikan Hias Soansari, LINI, LSM Telapak, dan beberapa tokoh masyarakat.

Metode pengambilan sampel dalam penelitian ini menggunakan teknik acak sederhana. Desa Les diambil secara purposif karena merupakan daerah yang mendapat sertifikat penerapan praktek perikanan terbaik (best practised). Kemudian diambil data jumlah nelayan keseluruhan dan jumlah nelayan ikan hias yang masih aktif serta telah tersertifikasi ramah lingkungan. Pengambilan responden berdasarkan cara penangkapan ikan yang di lakukan oleh nelayan. Adapun unit analisis dalam penelitian ini adalah rumah tangga sebagai unit terkecil dalam pengambilan keputusan keluarga, seperti mengukur tingkat pendapatan dan aspek-aspek lain yang mempengaruhi keadaan sosial ekonomi masyarakat nelayan. Berdasarkan data yang diperoleh dari Profil desa dan Kelurahan Desa Les tahun 2010, terdapat sejumlah 150 penduduk desa yang berprofesi sebagai nelayan. Diantaranya 50 orang merupakan nelayan ikan hias aktif yang juga merupakan anggota aktif kelompok nelayan ikan hias Soansari. Dengan demikian populasi dari penelitian ini adalah 50 nelayan ikan hias aktif dan sampel yang diambil dengan menggunakan teknik random sampling (pengambilan sampel acak sederhana). Teknik ini digunakan karena populasi memiliki karak- teristik yang homogen. Pengolahan dan analisis data menggunakan kuesioner yang dibagikan kepada responden dengan diolah melalui beberapa langkah, yaitu editing kuesioner, pengkodean data, pemindahan data ke lembar penyimpanan data, memasukkan data ke dalam program Microsoft Excel. Dalam penelitian kuantitatif, analisa data pada data primer dapat diolah dengan menggunakan tabulasi silang untuk menggambarkan karakteristik sampel. Data yang ditampilkan berupa grafik, diagram, atau bagan. Kemudian data tersebut digabungkan dengan hasil wawancara mendalam dan observasi berupa kutipan untuk kemudian penarikan kesimpulan dari semua data yang telah diolah sebelumnya.

\section{GAMBARAN UMUM LOKASI PENELITIAN}

Desa Les merupakan salah satu desa yang berada dalam Kecamatan Tejakula yang memiliki batas teritori wilayah, yakni sebelah utara berbatasan dengan Laut Bali, sementara sebelah selatan berbatasan dengan Hutan Bangli, Kecamatan Kintamani. Sebelah timur berbatasan langsung dengan Desa Penuktukan, sementara di sebelah barat berbatasan dengan Desa Tejakula, kedua desa tersebut masih di dalam satu kecamatan yang sama, yakni Kecamatan Tejakula. Beberapa desa di Kecamatan Tejakula biasanya dibatasi oleh sungai musiman yang melintas di antara dua desa. Desa Les terdiri atas sembilan dusun, yakni dusun Kanginan, Butiyang, Panjingan, Tegallinggah, Kawanan, Selonding, Tubuh, Lempedu, dan Dusun Panyumbahan.

Luas wilayah Desa Les adalah 769 hektar, termasuk di dalamnya hutan seluas 200 hektar dan wilayah pesisir seluas 135 hektar. Sebagian besar wilayah Desa Les merupakan tegalan atau ladang dan hutan lindung. Daerah persawahan hanya $4 \%$ sedangkan wilayah pemukiman umum hanya $6 \%$ dari total luas desa. Pantai Desa Les membujur dari barat ke timur sepanjang dua kilometer. Bentuk geografis Desa Les yang merupakan kombinasi dataran rendah dan dataran tinggi membuat suhu udara dan mata air desa ini cukup unik.

Topografi Desa Les bila dilihat secara melintang, laut Bali berada di sebelah utara desa dan perbukitan di sebelah selatan. Hal ini membuat suhu rata- rata di daerah pesisir ini cukup sejuk. Suhu rata-rata Desa Les adalah antara $25^{\circ} \mathrm{C}$ sampai $31^{\circ} \mathrm{C}$. Suhu akan sangat dingin bila malam dan pagi hari karena ada aliran udara yang berasal dari gunung. Sumber air Desa Les adalah mata air dari gunung yang berada di selatan desa dan air sumur bor. Kedua sumber air ini cukup berbeda, air dari pegunungan cenderung dingin dan segar dengan kadar salinitas nol. Berbeda dengan air sumur bor yang masih memiliki kadar salinitas yang cukup tinggi. Kondisi pantai berbatu mulai dari bongkahan batu ukuran kecil hingga sedang dan berpasir warna kelabu hingga hitam di mana warna kelabu ini merupakan hasil sisa dari letusan gunung api, yakni Gunung Agung (LINI, 2008). 
Mata pencaharian penduduk Desa Les beraneka ragam, seperti nelayan ikan konsumsi, nelayan ikan hias, pekerja bangunan, pedagang, dan beberapa pengusaha. Namun sebagian besar terkonsentrasi pada sektor pekerjaan nonformal bertani dan berternak. Jumlah nelayan ikan hias yang masih aktif ada sekitar 50 orang dan sekitar 100 orang lainnya merupakan nelayan ikan konsumsi. Ada empat kelompok nelayan di desa ini, salah satunya mengkhususkan diri sebagai kelompok nelayan ikan hias. Jumlah penduduk Desa Les adalah sebesar 7.453 jiwa pada tahun 2010. Jumlah penduduk perempuan sebesar 3.712 jiwa atau sekitar $49 \%$ seimbang dengan jumlah penduduk pria 3.741 jiwa sekitar $51 \%$ dari jumlah total penduduk Desa Les.

\section{HASIL PENELITIAN}

\section{Sosio-Ekologi Nelayan Ikan Hias}

Menurut Ditjen Perikanan Tangkap Kementrian Kelautan dan Perikanan (2007), nelayan adalah orang yang aktif melakukan pekerjaan dalam operasi penangkapan ikan atau binatang air lainnya atau tanaman air. Nelayan ikan hias adalah orang yang aktif melalukan penangkapan ikan hias di laut. Sedikit berbeda dengan nelayan pada umumnya (nelayan ikan konsumsi), nelayan ikan hias tidak terbagi atas penguasaan kapital, seperti yang dipaparkan Satria (2002). Terdapat nelayan pemilik yang memiliki sarana dan alat penangkapan, seperti perahu dan jaring. Namun tidak terdapat nelayan buruh (orang yang menjual jasa kepada pemilik kapal).

Ada dua tipe nelayan ikan hias di Desa Les, yakni nelayan skala besar dan nelayan skala kecil. Dalam praktek penangkapan ikan hias, nelayan skala besar melakukan kegiatan penangkapan hingga keluar Bali. Nelayan skala besar bekerja sama dengan nelayan kecil untuk bersamasama menangkap ikan dengan sistem upah bagi hasil setelah dipotong biaya operasional yang ditanggung oleh pemilik kapal. Nelayan ikan hias skala besar saat melaut memakan waktu seminggu hingga sebulan, sedangkan nelayan ikan hias skala kecil didefinisikan sebagai nelayan yang bekerja menangkap ikan sehari-hari dengan wilayah tangkap di pantai sepanjang utara Bali (tidak keluar pulau Bali).

Nelayan ikan hias terklasifikasi menjadi nelayan pinggiran dan nelayan kompresor. Nelayan pinggiran adalah nelayan ikan hias yang hanya menangkap ikan hias di wilayah pinggir pantai dengan kedalaman maksimum lima meter, sedangkan nelayan kompresor adalah nelayan yang menangkap ikan hias dengan menggunakan alat bantu pernapasan, kompresor. Biasanya nelayan kompresor menangkap ikan di kedalaman lebih dari lima meter. Nelayan kompresor membutuhkan perahu untuk menangkap ikan. Nelayan pinggiran hanya dengan menggunakan alat bantu, seperti masker dan fin. Perbedaan antara kedua tipe nelayan ini dijelaskan pada Tabel 1.
Tabel 1. Perbedaan Nelayan Pinggiran dan Nelayan Kompresor

\begin{tabular}{|c|c|c|}
\hline $\begin{array}{c}\text { Aspek } \\
\text { pembeda }\end{array}$ & Nelayan pinggiran & Nelayan kompresor \\
\hline Keahlian & $\begin{array}{l}\text { Nelayan yang hanya } \\
\text { menangkap ikan di } \\
\text { daerah pinggir pantai } \\
\text { dengan kedalaman } \\
\text { maksimal } 5 \mathrm{~m} . \\
\text { Memiliki kemampuan } \\
\text { menyelam tanpa alat } \\
\text { bantu napas }\end{array}$ & $\begin{array}{l}\text { Nelayan kompresor } \\
\text { biasanya menangkap } \\
\text { ikandi daerah dengan ke- } \\
\text { dalaman lebih dari } 5 \mathrm{~m} \text {. } \\
\text { Memiliki kemampuan } \\
\text { menyelam dengantehnik- } \\
\text { tehniknya agar tekanan } \\
\text { air tidak mempengaruhi } \\
\text { kinerja organ tubuh }\end{array}$ \\
\hline Alat & $\begin{array}{l}\text { Masker dan fin, serta } \\
\text { ban dalam yang berisi } \\
\text { oksigen untuk } \\
\text { membungkus ikan, } \\
\text { jaring penghalang, } \\
\text { serok, ban oksigen, } \\
\text { ember dekompresi, } \\
\text { plastik pembungkus }\end{array}$ & $\begin{array}{l}\text { Masker, fin, kompresor } \\
\text { (alat bantu napas) dan } \\
\text { perahu (untuk mencapai } \\
\text { lokasi penangkapan } \\
\text { ikan) juga ban yang } \\
\text { berisi oksigen untuk } \\
\text { pembungkusan ikan. } \\
\text { kompresor, jaring } \\
\text { penghalang, ember } \\
\text { dekompresi, plastik } \\
\text { pembungkus }\end{array}$ \\
\hline $\begin{array}{l}\text { Biaya } \\
\text { operasional }\end{array}$ & $\begin{array}{l}\text { Makan, dan biaya } \\
\text { mencapai lokasi } \\
\text { penangkapan }\end{array}$ & $\begin{array}{l}\text { Cenderung lebih tinggi } \\
\text { daripada nelayan } \\
\text { pinggiran: makan, dan } \\
\text { biaya ahan bakar untuk } \\
\text { kapal dan mesin } \\
\text { kompresor }\end{array}$ \\
\hline Jenis ikan & $\begin{array}{l}\text { Jenis ikanyang } \\
\text { ditangkap cenderung } \\
\text { lebih sedikit }\end{array}$ & $\begin{array}{l}\text { Jenis ikan yang } \\
\text { d itangkap lebih banyak } \\
\text { jenisnya }\end{array}$ \\
\hline
\end{tabular}

Selain nelayan ikan hias, pengepul ikan hias juga terklasifikasi menjadi dua tipe. Berdasarkan hasil observasi di lapang terdapat dua jenis pengepul di Desa Les, yakni pengepul kelompok dan pengepul swasta. Pengepul kelompok adalah pengepul yang merupakan bagian dari kelompok nelayan, tempat pengumpul ikan hias khusus untuk para nelayan anggota kelompok nelayan ikan hias Mina Bhakti Soansari. Terdapat tiga pengepul jenis ini di Desa Les, antara lain bapak K, bapak KN, dan bapak KW. Sementara itu, pengepul swasta dinamakan demikian karena pengepul tipe seperti ini merupakan pengepul yang dibentuk oleh perusahaan (swasta) eksportir untuk mempermudah perusahaan tersebut untuk memasok ikan hias. Salah satu perusahaan eksportir yang memiliki pengepul swasta adalah PT. BS. Pengepul swasta memilih untuk mendatangi nelayan ikan hias langsung untuk menyampaikan permintaan jenis dan banyaknya ikan hias.

Dalam prakteknya, sistem kerja pengepul dan nelayan di Desa Les ini bukanlah sistem patron-klien yang mengikat. Nelayan ikan hias bebas untuk memilih dalam memenuhi 
permintaan dari pengepul yang mana saja, baik pengepul kelompok maupun pengepul swasta. Nelayan ikan hias yang berjumlah 50 orang bebas memilih berpatron dengan salah satu dari tiga pengepul kelompok yang ada di desa ini. Ikatan patron-klien antara nelayan dan pengepul biasanya dilandaskan pada dasar kekeluargaan, misalnya nelayan merupakan saudara sepupu salah satu pengepul, sehingga nelayan tersebut merasa harus setia kepada pengepul yang merupakan saudaranya itu.

Masyarakat nelayan menurut Satria (2002) digambarkan memiliki karakteristik tertentu yang cenderung berbeda dengan masyarakat lain yang tidak tinggal di daerah pesisir. Termasuk masyarakat nelayan ikan hias Desa Les yang memiliki karakteristik seperti nelayan pada umumnya, diantaranya:

1. Sistem pengetahuan, pengetahuan mengenai teknik penangkapan ikan hias umumnya diperoleh secara turun temurun dengan didasarkan kepada pengalaman empirik. Pengetahuan lokal yang berkembang mengenai teknik penangkapan ikan hias di Desa Les sebelum tahun 2000-an adalah sistem penangkapan yang menggunakan potassium-sianida. Sistem pengetahuan berubah dengan mengadopsi sistem pengetahuan baru yang lebih ramah lingkungan yang dikenalkan oleh para LSM. Pengetahuan baru ini kemudian diinternalisasi oleh masyarakat nelayan ikan hias Desa Les menjadi pengetahuan lokal (new local knowledge). Kuatnya pengetahuan lokal ini menjadi salah satu faktor terjaminnya kelangsungan hidup sebagai nelayan ikan hias di Desa Les. Sistem pengetahuan lain yang berkembang di Desa Les adalah penentuan musim penangkapan ikan hias. Misalnya bulan Juni hingga Juli dikenal sebagai waktunya dewa memakan bintang oleh masyarakat Bali, sehingga angin dan ombak di pantai tidak dapat diprediksi kapan datangnya.

2. Sistem kepercayaan, nelayan masih memiliki kepercayaan yang kuat bahwa laut memiliki kekuatan khusus dalam aktivitas penangkapan ikan agar keselamatan dan hasil tangkapan terjamin. Sistem kepercayaan yang dianut oleh masyarakat Desa Les sejalan dengan ajaran agama Hindu-Bali. Masyarakat nelayan Desa Les akan mengadakan upacara "sedekah laut" setiap satu tahun sekali sebagai wujud terima kasih masyarakat kepada laut yang telah memberi penghidupan. Upacara ini dilakukan oleh seluruh keluarga nelayan dengan bersembahyang di Pura Dalem dengan menyajikan babi guling dan berbagai sesajen lainnya yang kemudian dihanyutkan ke laut. Tradisi ini dilangsungkan tidak hanya sebagai instrumen stabilitas sosial dalam komunitas nelayan melainkan juga sebagai salah satu bentuk upacara agama Hindu-Bali. Upacara tumpek yang diadakan satu bulan sekali (hitungan Bali 1 bulan adalah 35 hari) juga merupakan upacara sembahyang sebagai ungkapan rasa terima kasih masyarakat atas kebahagian yang diperoleh atas kemurahan yang telah diberikan Tuhan dalam satu bulan. Bagi nelayan pada sembahyang ini mengucap syukur atas hasil tangkapan yang didapat dari laut.

3. Peran wanita, istri nelayan dominan dalam hal mengatur ekonomi rumah tangga sehari-hari sehingga sepatutnya dilibatkan dalam program pengembangan masyarakat. Desa Les belum memiliki program pengembangan masyarakat. Istri nelayan dilibatkan dalam program pelesatrian lingkungan, misalnya dalan kegiatan rehabilitasi karang. Istri nelayan diajarkan cara melakukan penyetekan karang pada substrat buatan untuk kemudian ditanam di laut oleh para nelayan. Selain itu peran istri nelayan tercermin dalam kegiatan melaut nelayan sehari-hari. Istri-istri nelayan biasa mengantar para nelayan melaut sambil membawakan bekal makan siang. Istri juga turut membantu saat para nelayan menurunkan kapal untuk melaut dan menaikkan kapal setelah melaut

4. Struktur sosial, struktur yang terbentuk dalam hubungan produksi (termasuk pasar) dalam usaha perikanan, perikanan tangkap maupun perikanan budidaya, umumnya dicirikan dengan ikatan patronklien yang kuat. Kuatnya hubungan ini konsekuensi akibat ketidakpastian dan resiko yang tinggi dalam penangkapan ikan. Namun pada nelayan ikan hias Desa Les, berdasarkan hasil wawancara mendalam dengan beberapa nelayan dan pengepul, baik pengepul swasta dan pengepul kelompok, bahwa ikatan patronklien di desa ini tidak kuat. Nelayan bebas memenuhi permintaan ikan hias oleh pengepul yang mana saja, nelayan tidak terikat untuk menyerahkan hasil tangkapannya untuk satu pengepul saja. Tidak kuatnya hubungan ini akibat rendahnya konsekuensi ketidakpastian dan resiko dalam penangkapan ikan. Bentuk stratifikasi sosial masyarakat Desa Les cenderung beragam. Modernisasi membuat diferensiasi soaial semakin terlihat. Hal ini dapat dilihat dari semakin bertambahnya jumlah posisi sosial yang terjadi lebih mengarah kepada stratifikasi yang vertikal, berjenjang menurut ekonomi, prestise, atau kekuasaan. Namun, stratifikasi sosial masyarakat nelayan ikan hias tidak terlalu mencolok. Akan tetapi posisi sosial nelayan ikan hias mulai meningkat karena praktek perikanan yang dilakukan telah ramah lingkungan. Tidak ada lagi nelayan ikan hias yang melanggar hukum. Modernisasi yang terjadi disini adalah dalam bentuk modernisasi cara tangkap yang lebih bermartabat, melestarikan lingkungan.

5. Posisi sosial nelayan, rendahnya posisi sosial nelayan ini merupakan akibat dari keterasingan nelayan sehingga masyarakat bukan nelayan tidak mengetahui lebih jauh cara hidup nelayan. Hal ini terjadi akibat sedikitnya waktu dan kesempatan nelayan untuk berinteraksi dengan masyarakat lain karena alokasi waktu yang besar untuk kegiatan penangkapan ikan dibanding untuk bersosialisasi dengan masyarakat bukan nelayan yang memang secara geografis relatif jauh dari pantai. Nelayan ikan hias Les cenderung 
memiliki posisi sosial yang cukup tinggi. Nelayan tidak mengalami keterasingan, karena nelayan terdedah informasi. Keterdedahan informasi nelayan ikan hias Desa Les melalui sarana-sarana komunikasi yang terdapat di desa ini, yakni televisi, radio, serta informasi dan pengetahuan dari para peneliti dan aktivis lingkungan yang sering melakukan penelitian di Les. Sifat nelayan Les yang terbuka dengan pengetahuan dan informasi membuat nelayan ikan hias tidak tertinggal meskipun tingkat pendidikan nelayan yang rendah. Bahkan terdapat nelayan yang hanya memiliki tingkat pendidikan sedang mampu berbahasa inggris dengan cukup baik. Secara politis, posisi nelayan ikan hias berada dalam posisi independen namun marjinal akibat dari faktor kapital yang dimilikinya sangatlah terbatas. Sehingga pada beberapa sektor memiliki kendala yang cukup berarti karena nilai politik yang dimiliki nelayan masih rendah.

Sarana yang digunakan nelayan ikan hias untuk menangkap ikan bagi nelayan kompresor adalah perahu yang terbuat dari kayu khusus berukuran sedang dengan kayu penyeimbang di salah satu sisinya. Nelayan tidak menggunakan perahu yang terbuat dari fiber karena cenderung lebih mahal dan tidak tahan gesekan dan mudah pecah dibanding perahu yang terbuat dari kayu. Di Desa Les terdapat belasan perahu nelayan (tidak hanya perahu nelayan ikan hias melainkan juga perahu nelayan ikan konsumsi). Biasanya perahu ditempeli motor $15 \mathrm{PK}$ sebagai sumber tenaga dan di tengah perahu terdapat kompresor sebagai sumber udara untuk menyelam. Bahan bakar kompresor dan bahan bakar motor tempel adalah bensin. Mesin akan diganti biasanya dalam setahun satu kali, karena salinitas yang tinggi mesin-mesin ini mudah terkena korosi. Sekali melaut biasanya satu perahu akan berisi dua sampai tiga orang, sehingga biaya operasional dalam sekali melaut ditanggung bersama sehingga lebih ringan.

Nelayan pinggirian menggunakan sarana yang lebih praktis, yakni hanya alat selam berupa masker, fin, dan ban dalam yang digunakan sebagai pengapung keranjang tempat mengumpulkan ikan selain sebagi tempat penyimpanan cadangan oksigen untuk pembungkusan ikan hias. Biaya operasional yang ditanggung nelayan pinggiran adalah biaya untuk mencapai lokasi penangkapan yang lebih sering di Desa Penuktukan (sebelah timur Desa Les) dan biaya makan siang nelayan. Peralatan tangkap yang digunakan oleh nelayan ikan hias pinggiran maupun nelayan kompresor sebelum tahun 2000 adalah botol yang berisi cairan sianida untuk memingsankan ikan. Alat tersebut adalah salah satu alat pendukung penangkapan yang menghancurkan alam (destructive fishing). Nelayan ikan hias Les telah beralih menggunakan alat tangkap yang lebih ramah lingkungan, yakni jaring penghalang (barrier net) dan serok (scoopnet). Alat lain yang mendukung penangkapan ikan yang ramah lingkungan ini adalah ember atau keranjang dekompresi, oksigen dan plastik untuk pembungkusan ikan hias pasca penangkapan agar mudah dibawa ke pengepul.

Tabel 2. Jenis Alat Tangkap Ikan Hias dan Fungsinya

\begin{tabular}{|c|c|}
\hline $\begin{array}{c}\text { Jenis alat } \\
\text { tangkap }\end{array}$ & Fungsinya \\
\hline $\begin{array}{l}\text { Jaring } \\
\text { penghalang } \\
\text { (barrier net) }\end{array}$ & $\begin{array}{l}\text { Digunakan nelayan untukmenghalangi ikan. } \\
\text { Nelayan meletakkan jarring ditempat yang } \\
\text { banyak ikan hias yang akan ditangkap, } \\
\text { diletakkan dengan posisi jaring melawan arus, } \\
\text { sehingga terbentuksetengahlingkaran. Nelayan } \\
\text { akan menggiring ikan kearah jarring } \\
\text { penghalang, saat ikan telah terjebak di jaring, } \\
\text { maka nelayan dengan serok mengambil ikan } \\
\text { kemudian dimasukkan ke dalam ember } \\
\text { dekompresi. Jaring penghalang menggunakan } \\
\text { bahan khusus yang tidak melukai ikan hias }\end{array}$ \\
\hline $\begin{array}{l}\text { Serok } \\
\text { (scoopnet) }\end{array}$ & $\begin{array}{l}\text { Serok digunakan nelayan untuk mengambil } \\
\text { ikan yang telah terjebak pada jaring } \\
\text { penghalang }\end{array}$ \\
\hline $\begin{array}{l}\text { Ember } \\
\text { dekompresi }\end{array}$ & $\begin{array}{l}\text { Ember dekompresi digunakan sebagai tempat } \\
\text { menyimpan ikan hasil tangkapan di dalam } \\
\text { laut untuk dibawa ke perahu dan kemudian di } \\
\text { bungkus di atas kapal }\end{array}$ \\
\hline
\end{tabular}

Pengelolaan sumber daya laut Les membutuhkan perhatian yang lebih intensif. Salah satu bentuk pengelolaan tersebut adalah dengan menerapkan Daerah Perlindungan Laut (DPL). Salah satu DPL Kecamatan Tejakula adalah wilayah perairan Les sebagian wilayah terumbu karang seluas $200 \mathrm{~m}^{2}$ (Yahya et al., 2006). DPL diterapkan untuk memulihkan kondisi sumber daya yang sedang direhabilitasi sebelum dapat dieksplorasi kembali. Pengelolaan sumber daya laut Les ditujukan untuk membentuk wilayah penangkapan ikan hias bagi nelayan.

Setiap komunitas nelayan memiliki wilayah penangkapan (fishing ground) ikan tertentu. Wilayah penangkapan adalah area khusus yang digunakan nelayan sebagai tempat mencari ikan hias. Penentuan wilayah tangkap biasanya tergantung pada arah angin dan ombak. Di Desa Les penentu wilayah tangkap lainnya adalah batas administratif yang ditetapkan oleh desa secara otonomi. Sebenarnya bagi nelayan Desa Les tidak ada batasan wilayah tertentu dalam mencari ikan, sepanjang garis pantai Desa Les nelayan bebas menangkap ikan. Akan tetapi ada beberapa pihak yang menetapkan daerah larang tangkap khusus bagi nelayan ikan hias Desa Les. Larangan tersebut muncul dari pihak pemerintahan desa tetangga maupun resort-resort yang terdapat di sepanjang wilayah pantai utara Bali. Pada UU No. 32 Tahun 2004 tentang Otonomi Daerah disebutkan bahwa pemerintah pusat menyerahkan wewenang kepada pemerintah daerah untuk memanfaatkan segala potensi atas sumber daya alam yang ada di daerahnya masing-masing. Otonomi daerah memperkenankan setiap badan pemerintahan bahkan Desa sekalipun untuk membuat peraturan yang berkaitan dengan pemanfaatan potensi sumber daya daerahnya. Beberapa desa sepanjang pantai utara Bali, dalam wilayah administratif Kecamatan Tejakula, memetakan wilayah 
laut desanya. Pemetaan ini ditujukan untuk mempersempit ruang gerak nelayan dari desa lain untuk mengambil ikan dari wilayah laut desa tersebut. Ditambah pemetaan yang dilakukan oleh beberapa resort yang mengkapling laut untuk tidak dimasuki oleh pihak lain selain tamu.

Berdasarkan klasifikasi tipe kepemilikan sumber daya bersama Ostrom dan Undang-Undang Dasar RI 1945, maka laut merupakan hak kepemilikan pemerintah sebagai owner dan masyarakat dapat bertindak sebagai claimant. Sebagai owner, pemerintah memiliki hak kepemilikan yang kolektif untuk berpartisipasi dalam mengelola dan mengekslusi juga memegang hak aleanasi (hak menjual atau menyerahkan hak kepemilikan). Berdasarkan keterangan di atas, pemerintah memiliki hak untuk eksklusi pihak-pihak tertentu dalam memanfaatkan sumber daya laut. Dalam hal ini tidak menutup kemungkinan pemberian hak oleh pemerintah setempat kepada resort untuk mengelola laut. Intepretasi dari hak ini kemudian diartikan oleh resort sebagai hak untuk mengeksklusi pihak lain (nelayan). Masyarakat dalam konteks ini, nelayan, yang hanya memiliki hak claimant, hak masuk dan memanfaatkan hasil sumber daya alam, juga hak untuk mengelola sumber daya alam. Nelayan tidak mendapat 'jatah' hak eksklusi dari pemerintah.

Laut dapat dikategorikan sebagai sumber daya bersama yang menurut Robbins (2004) dan Ostorm (1999) merupakan sistem ekologi yang kompleks. Akan ada biaya yang dikeluarkan untuk mengeksklusi pihak lain. Sumber daya bersama biasanya memiliki dilema dalam pengelolaannya, yang diterangkan teori sumber daya bersama "Theory of Tragedy of the Commons" oleh Garret Hardin. Diperlukan sentralisasi dan privatisasi untuk mengatasi dilema pengeloaan sumber daya bersama. Pengelolaan sumber daya yang kolektif menurut Ciriacy-Wantrup dan Bishop (1975) dalam Robbins (2004) merupakan fakta bahwa sumber daya bersama tidak ada yang memiliki (secara legal, res nullius) tapi sebenarnya memiliki hak kepemilikan bersama yang dimiliki oleh masyarakat setempat (secara legal, res communes). Laut secara luas tidak ada yang memiliki, namun laut yang berada di dekat daerah tertentu maka pengelolaannya akan dilakukan oleh daerah tersebut, sehingga laut merupakan milik masyarakat (res communes).

Sejak nelayan Les berhasil merubah pola tangkap menjadi lebih ramah lingkungan, beberapa desa di Kecamatan Tejakula mengeluarkan peraturan yang melarang nelayan Les untuk menangkap ikan di wilayah desa tersebut. Alasan yang mengemuka dari pihak swasta dan pemerintah desa tetangga adalah bahwa nelayan Les adalah nelayan perusak lingkungan. Para pemangku kepentingan tersebut tidak ingin daerahnya dirusak oleh nelayan Les. Dengan dibatasinya hak akses, nelayan Les tidak memiliki hak untuk menangkap ikan dan mengelola laut tersebut. Nelayan menjadi dibatasi ruang geraknya. Hal ini merupakan salah satu kendala bagi nelayan dalam proses penangkapan ikan hias. Nelayan merupakan masyarakat pesisir yang sangat bergantung kepada alam. Terjadinya benturan kepentingan ini membuat nelayan yang berada pada pihak yang lemah termarginalisasi. Pengelolaan laut menjadi terpolitisasi oleh adanya intervensi dari pemerintahan desa tetangga dan resort sebagai pihak swasta yang memiliki eksklusifitas dalam memanfaatkan laut.

Nelayan ikan hias dalam melaksanakan profesinya sangat bergantung kepada alam. Cuaca dan ombak adalah faktor utama yang menentukan bagi nelayan ikan hias. Cuaca buruk dan angin kencang sering menjadi kendala bagi nelayan menangkap ikan hias. Cara tangkap dengan menyelam tentu menjadi terganggu dengan adanya angin kencang dan ombak. Penentuan musim tangkap merupakan hasil dari sistem pengetahuan yang turun temurun di Desa Les. Masih ada beberapa keluarga nelayan yang percaya dengan mitos, misalnya bulan Juni hingga Juli dikenals ebagai waktunya dewa memakan bintang, sehingga angin dan ombak di pantai tidak dapat diprediksi kapan datangnya. Nelayan ikan hias berangkat menangkap ikan pada pagi hari dan pulang pada siang harinya. Sebagian besar nelayan tidak akan melakukan kegiatan melaut saat mendekati musim penghujan dan musim angin barat, karena laut akan keruh sehingga susah untuk menangkap ikan. Sedangkan pada musim kemarau, kegiatan menangkap ikan menjadi lebih giat karena cuaca cenderung berpihak kepada nelayan. Menurut pengalaman nelayan Desa Les, bulan Desember, Januari, dan Februari adalah bulan yang jelek untuk menangkap ikan. Secara ilmu alam, pada bulan tersebut angin barat sedang bertiup kencang. Sedangkan bulan Agustus hingga Desember merupakan musim angin timur yang menguntungkan nelayan untuk menangkap ikan. Laut cenderung lebih tenang dan jernih. Nelayan dapat menangkap ikan lebih banyak pada bulan-bulan ini.

\section{Kondisi Perikanan Ikan Hias Pra-Pelabelan Ramah Lingkungan (Ecolabelling)}

Desa Les, Kecamatan Tejakula, Kabupaten Buleleng, Propinsi Bali merupakan salah satu wilayah penghasil ikan hias ramah lingkungan di Indonesia. Sebelum tahun 1982 hanya terdapat nelayan ikan pelagis (konsumsi) di Desa Les. Namun karena banyak nelayan dari Pulau Jawa yang mencari ikan hias di desa ini, nelayan Les mulai tertarik mempelajari apa yang sedang dilakukan oleh nelayan jawa tersebut. Nelayan Les mulai beralih dari profesi sebagai nelayan ikan konsumsi (pelagis) menjadi nelayan ikan hias sejak saat itu. Cara tangkap yang dilakukan pada waktu itu adalah dengan menggunakan jaring yang tradisional.

Sejalan dengan meningkatnya permintaan pasar serta tergiur kemudahan yang ditawarkan penggunaan sianida nelayan kemudian beralih menggunakan sianida. Sianida adalah senyawa kimia yang mengandung komplek siano dengan hubungan karbon dan nitrogen yang terikat tiga. 
Senyawa ini melepaskan $\mathrm{CN}$ - yang sangat beracun (Wikipedia). Pemakaian dalam jangka waktu yang lama akan mengakibatkan kerusakan pada terumbu karang. Nelayan terkonsentrasi untuk memenuhi kebutuhan rumah tangganya, hingga mengeksploitasi sumber daya alam untuk memenuhi permintaan pasar (Bryant dan Bailey, 2005). Akibat aktivitas penangkapan yang merusak, laut sebagai sumber utama mata pencaharian nelayan mulai menunjukkan kerusakan.

Kondisi perikanan ikan hias Desa memiliki sejarah yang tidak singkat dapat dilihat pada Gambar 2. Hampir tiga dasawarsa dari tahun 1982 hingga 2011 perikanan ikan hias Desa Les terus berkembang. Meski diwarnai dengan prestasi yang tidak membanggakan diawal, nelayan ikan hias masih tetap bertahan sampai sekarang. Dua dasawarsa pertama, nelayan ikan hias Les menggunakan sianida sebagai alat utama dalam penangkapan ikan. Dengan pola tangkap "sikat-habis" nelayan mengeksploitasi sumber daya alam laut Les. Kegiatan melanggar hukum ini dilakukan secara sembunyisembunyi oleh nelayan dari aparat penegak hukum, seperti polisi air.

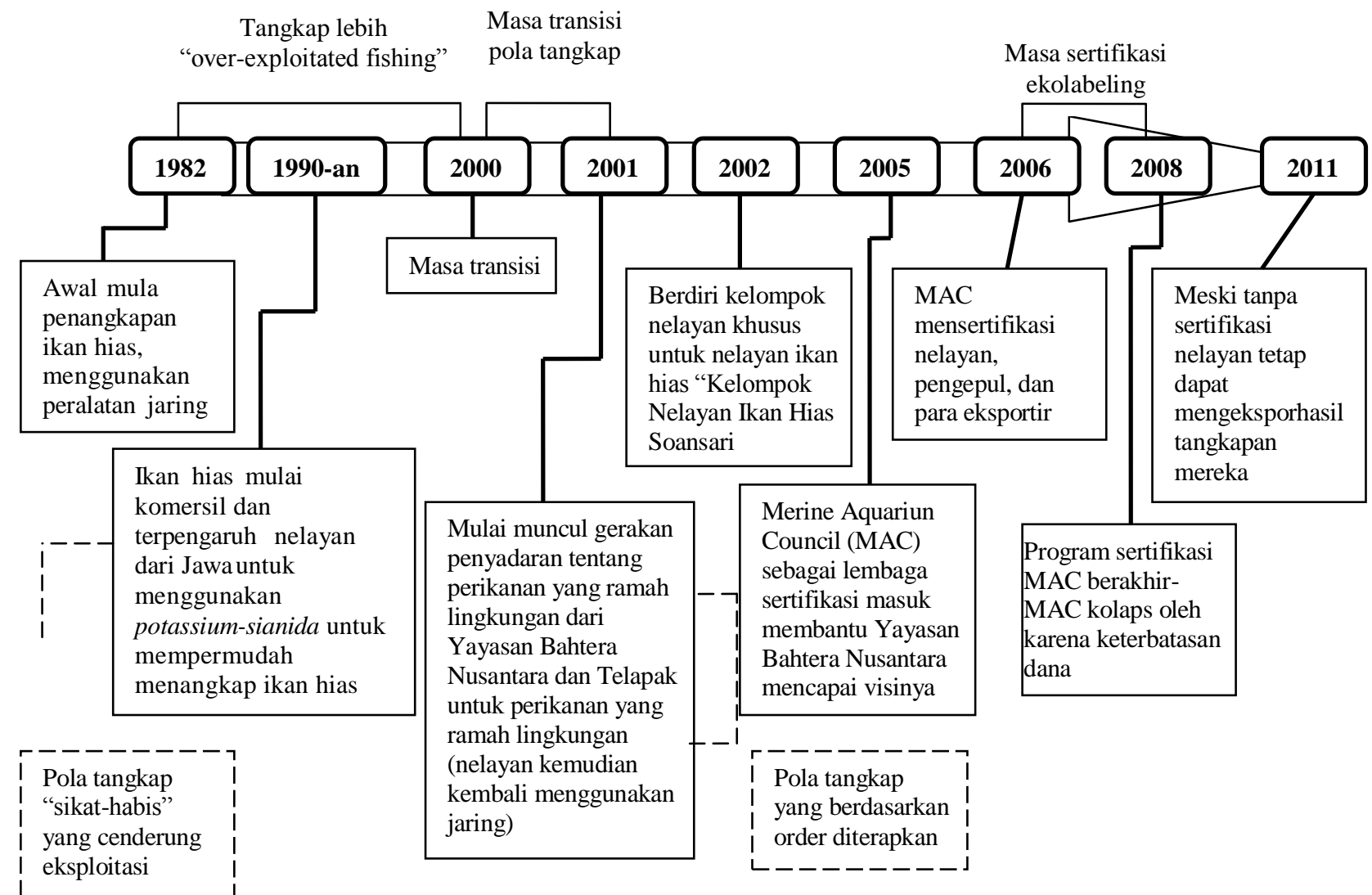

Gambar 2. Sejarah Perikanan Ikan Hias di Desa Les, Bali (1982-2011)

Beberapa alasan nelayan ikan hias tetap menggunakan sianida dalam upaya penangkapannya, walaupun nelayan mengetahui perbuatan tersebut melanggar hukum adalah:

1. Pengetahuan nelayan, nelayan tidak mengetahui cara lain untuk menangkap ikan hias. Ini merupakan alasan yang paling sering dikemukakan oleh responden penelitian ini. Menggunakan sianida sudah menjadi pengetahuan turun temurun. Untuk tetap bertahan hidup, nelayan harus memilih untuk tetap menangkap ikan dengan sembunyi-sembunyi seperti ini atau tidak makan sama sekali. Nelayan dihadapkan kepada dua pilihan yang dilematis. Nelayan ikan hias Les sering ditahan karena pelanggaran hukum menggunakan sianida dalam upaya menangkap ikan. Meski begitu tidak adanya solusi dari pemerintah, pihak pemerintah hanya memberi hukuman tanpa memberi solusi apa yang seharusnya dilakukan nelayan, sehingga setelah bebas dari hukuman melakukan pelanggaran tersebut kembali. Nelayan tidak mempunyai pilihan lain.

2. Kesadaran nelayan, nelayan tidak menyadari dampak dari cara penangkapan yang dilakukannya. Sianida baru disadari nelayan dapat merusak ekosistem laut setelah lebih hampir dua puluh tahun nelayan menggunakannya.

3. keterdesakan ekonomi, keterdesakan ekonomi membuat nelayan melakukan strategi apapun untuk memenuhi kebutuhannya. Kesadaran akan kerusakan lingkungan yang terjadi akibat penggunaan sianida tidak cukup membuat nelayan untuk berhenti melakukannya. Pengetahuan cara tangkap ikan hias selain menggunakan sianida juga dirasa tidak cukup untuk 
menghentikan penggunaan sianida selama hal tersebut tidak menutupi keterdesakan ekonomi nelayan. Nelayan terkonsentrasi untuk memenuhi kebutuhan rumah tangganya, hingga mengeksploitasi sumber daya alam untuk memenuhi permintaan pasar (Bryant dan Bailey, 2005).

Kerusakan terumbu karang yang terjadi mengakibatkan ekosistem laut Les terganggu. Ekosistem merupakan bentuk hubungan timbal balik antara komponen hidup (biotik) dan komponen tak hidup (abiotik) di suatu tempat yang berinteraksi membentuk kesatuan yang teratur dan membentuk jaring-jaring kehidupan pada berbagai tingkatan organisasi (Silalahi, 2001; Adibowo, 2007). Terumbu karang, anemon, bintang laut, berbagai jenis ikan karang (ikan hias), dan rumput laut merupakan bagian dari ekosistem laut Les. Kerusakan satu mata rantai ekosistem akan merusak jaring-jaring kehidupan rantai lainnya. Kerusakan terumbu karang, dalam hal ini efek negatif dari penggunaan sianida dalam jangka waktu yang lama membuat jaring kehidupan antara ikan-ikan hias dan biota lainnya terganggu.

Kondisi laut Les yang mencapai titik kritis kemudian membawa nelayan pada masa transisi. Ketiadaan ikan di laut mempengaruhi pendapatan nelayan. Pada satu sisi nelayan sadar bahwa keadaan ini terjadi hasil dari praktek perikanan yang tidak memperhatikan lingkungan. Nelayan ikan hias harus segera mengambil keputusan apa yang akan dilakukan. Di tengah kebingungan ini, masuklah Lembaga Swadaya Masyarakat (LSM) lokal Bali Yayasan Bahtera Nusantara dengan dibantu oleh Telapak Indonesia melakukan penyadaran kepada nelayan dalam program pelestarian lingkungan, perikanan ramah lingkungan. Dengan bantuan dan pendampingan dari teman-teman LSM, nelayan kemudian beralih menggunakan jaring dan serok sebagai alat utama penangkapan ikan hias yang lebih ramah lingkungan. Perubahan yang terjadi dalam bentuk perubahan alat dan cara tangkap pola tangkap, penanganan ikan pascatangkap oleh nelayan, penanganan ikan oleh pengepul, dan selanjutnya. LSM juga membantu nelayan untuk membentuk sebuah wadah organisasi nelayan sebagai tempat bertukar informasi, pengetahuan, dan pengalaman, untuk menguatkan kebersamaan para nelayan ikan hias. Berdirilah Kelompok Nelayan Ikan Hias Mina Bhakti Soansari pada tanggal 29 Oktober 2002 dengan beranggotakan 60 orang nelayan ikan hias.

Berita bahwa Desa Les telah menerapkan perikanan yang ramah lingkungan dengan baik (best practise) menyebar luas, sehingga Marine Aquarium Council (MAC) Indonesia pada tahun 2005 tertarik untuk membantu dan memonitor kegiatan perikanan ramah lingkungan di Les. Kemudian pada tahun 2006 MAC sebagai lembaga sertifikasi menggandeng pihak ketiga untuk menilai praktek perikanan yang tengah dilakukan di Desa Les. MAC mensertifikasi para nelayan ikan hias, pengepul, dan eksportir yang telah memenuhi kriteria ramah lingkungan. PRL ini sempat berjalan selama dua tahun sebelum MAC kolaps pada tahun 2008 karena kekurangan dana operasional. Sekarang, meski tanpa PRL yang dikeluarkan oleh MAC nelayan ikan hias Les tetap menerapkan praktek perikanan yang ramah lingkungan.

Perubahan sosial merupakan perubahan pada sistem sosial yang berkembang dan yang menjadi konsep dasar perubahan tersebut adalah perbedaan, perbedaan momen, dan berada di antara sistem sosial yang sama (Sztompka, 1994). Komponen dan dimensi yang mungkin berubah dalam suatu perubahan sosial adalah komposisi, struktur, fungi, batas, dan hubungan antara sub-sistem dalam sistem sosial. Perubahan yang terjadi di Desa Les merupakan perubahan sosial, khususnya bagi masyarakat nelayan karena mengubah konsep dasar dari sistem sosial nelayan ikan hias. Adapun komponen dan dimensi yang mengalami perubahan di Desa Les adalah:

1. dimensi struktural, dimensi struktural yang berubah dari Desa Les antara lain perubahan pada institusi nelayan, akat tangkap nelayan ikan hias, cara tangkap nelayan ikan hias, mata pencaharian utama nelayan, mata pencaharian sampingan nelayan;

2. dimensi kultural, perubahan pada dimensi kultural terjadi dari proses penyadaran (afektif) dan pada ranah kognitif pada nelayan ikan hias. Perubahan pola pikir dan cara pandang nelayan ikan hias dalam memandang sumber daya laut, interaksi antar pemangku kepentingan, modal sosial yang berubah.

Faktor-faktor penyebab perubahan sosial tersebut antara lain:

1. perubahan komposisi nelayan, perubahan komposisi yang terjadi adalah jumlah nelayan ikan hias yang bertahan tetap berprofesi sebagai nelayan ikan hias. Masa transisi membuat beberapa nelayan ikan hias memutuskan untuk beralih profesi. Perubahan pola tangkap yang terjadi juga turut memangkas jumlah nelayan ikan hias di desa ini;

2. perubahan struktur sosial, terjadi perubahan struktur dalam masyarakat nelayan Desa Les, perubahan pola tangkap mempengaruhi berubahnya instutsi nelayan. Nelayan ikan hias Les, sekarang telah memilki institusi kelembagaan khusus. Dalam masyarakat, nelayan ikan hias mengalami kenaikan nilai sosial (social climbing) yang berarti;

3. perubahan fungsi sosial nelayan, perubahan fungsi peran terjadi pada nelayan. Nelayan mengalami fungsi peran ganda saat ini, selain sebagai penangkap ikan juga sebagai penjaga kelestarian laut. Sebelumnya nelayan dianggap sebagai perusak sumber daya alam;

4. perubahan batas, perubahan batas wilayah tangkap yang terjadi di Les adalah semakin menyempitnya ruang gerak nelayan ikan hias untuk menangkap ikan;

5. perubahan pada hubunguan subsistem, terjadi pula perubahan pola hubungan antar pemangku kepentingan perikanan ikan hias. Hubungan patron klien 
menjadi lebih longgar. Perubahan sosial tidak terjadi dengan sendirinya. Ada pihak tertentu yang mendorong hal ini untuk terjadi. Dalam konteks nelayan ikan hias Desa Les, perubahan ini dimotori oleh Lembaga Swadaya Masyarakat. Robbins (2004) dalam bukunya "Political Ecology" menyampaikan bahwa perubahan sosial dapat terjadi saat ada perubahan rezim pola pengelolaan lingkungan dan perubahan lingkungan yang kemudian menghasilkan keuntungan untuk kelompok masyarakat setempat untuk memperoleh keamanan dan pengakuan politik. Perubahan sosial dan identitas lingkungan di suatu daerah mencerminkan degradasi dan marginalisasi lingkungannya. Perubahan sosial di Les menggambarkan degradasi laut Les yang sudah pada sampai titik yang mengkhawatirkan membuat nelayan ikan hias semakin termarginalkan dengan keadaan tersebut.

Kondisi perikanan ikan hias Desa Les yang ramah lingkungan merupakan sebuah proses yang panjang yang memerlukan proses pendekatan oleh LSM. Selanjutnya proses pendampingan dilakukan selama perubahan terjadi. Lembaga Swadaya Masyarakat (LSM) memiliki peran penting dalam transformasi perikanan yang terjadi di Desa Les. Upaya penyadaran yang kemudian menghasilkan sikap dan perilaku yang positif dari para nelayan merupakan salah satu bentuk kesuksesan LSM dalam menjalankan program pelestarian lingkungan. Adapun LSM yang turut andil dalam kesuksesan ini adalah Yayasan Bahtera Nusantara sebagai LSM lokal Bali dan Telapak Indonesia. Program penyadaran yang dilakukan memerlukan waktu yang cukup lama untuk diadaptasi oleh masyarakat nelayan.

Pendekatan yang dilakukan oleh LSM adalah dengan datang ke nelayan Les berpura-pura sebagai eksportir dari Denpasar yang hanya mau membeli ikan-ikan hasil tangkapan yang ramah lingkungan, tidak menggunakan sianida. Perusahaan eksportir ini akan membayar lebih kepada nelayan untuk ikan-ikan yang ramah lingkungan. Seminggu dua sampai tiga kali beberapa utusan perusahaan ini datang ke Les menunjukkan cara-cara menangkap ikan tanpa sianida. Kemudian nelayan mulai mengikuti cara-cara yang diajarkan tersebut karena dianggap mudah dan lebih tinggi harga ikannya.

Setelah nelayan menunjukkan sikap siap untuk menerima perubahan ini, LSM kemudian mencoba mengumpulkan para nelayan ikan hias untuk bertukar pikiran bersama. Pada kesempatan itu LSM memberitahukan identitas sebenarnya dan mengajak masyarakat nelayan untuk bersinergi mengembalikan kelestarian ekosistem laut Les. Dalam upaya ini ada beberapa hal yang mengalami perubahan hasil dari pendampingan ini. Adapun perubahan yang terjadi antara lain:

1. Berubahnya pola pengambilan ikan hias di laut. Pola pengambilan ikan hias bersistem "lihat-tangkap" tanpa memperdulikan berapa banyak ikan yang ditangkap. Padahal hanya beberapa ikan saja yang diperlukan, namun untuk mengejar pendapatan yang tinggi nelayan cenderung menangkap semua ikan yang ada di dekat mereka. Bila hasil tangkapan melebihi yang diminta oleh pengepul, maka ikan selain permintaan akan buang begitu saja. Pola nelayan ikan hias menangkap ikan beralih menjadi sistem tergantung permintaan (by order), banyak ikan yang diambil disesuaikan dengan permintaan dari pengepul atau eksportir. Hal ini dilakukan untuk menjaga keberlimpahan dan keanekaragaman ikan. Ikan yang tidak diambil kemudian akan dapat tetap berkembang biak di alam. Hasil tangkapan nelayan kemudian diserahkan kepada pengepul atau eksportir sesuai permintaan. Pembayaran upah dilakukan dengan menghitung harga masing-masing organisme yang ditangkap. Harga ikan hias ditingkat pengepul bervariasi antara $\mathrm{Rp} 1000,00$ (seribu rupiah) hingga Rp15.000,00 (lima belas ribu rupiah) per ekornya. Slip biasa diberikan pengepul kepada nelayan beserta sejumlah uang yang diterima nelayan dari hasil tangkapnnya pada saat penyerahan ikan hias.

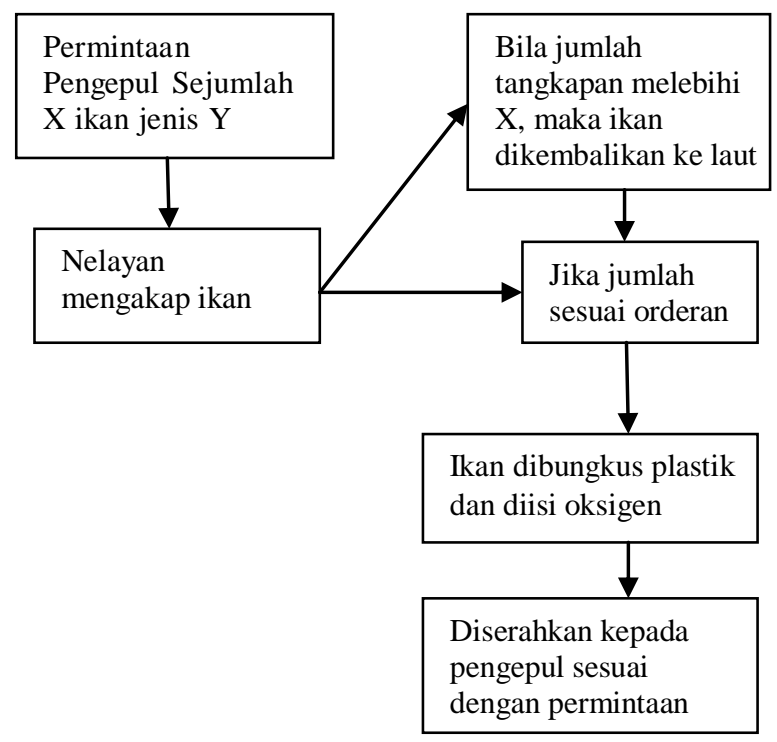

Gambar 3. Skema Penangkapan Ikan By Order (sesuai Permintaan)

2. Berubahnya alat tangkap yang digunakan. Perubahan dilakukan pada alat tangkap yang digunakan. Dari penggunaan bahan berbahaya sianida, menjadi menggunakan jaring penghalang (barrier net) dan serok (scoopnet). Jaring penghalang digunakan sebagai penghalang ikan hias agar tidak lari terlalu jauh dan serok (scoopnet) untuk menangkap ikan hias yang terjebak di jaring penghalang. Selanjutnya ikan yang telah tertangkap serok kemudian diletakkan di dalam ember dekompresi. Ember dekompresi adalah ember yang dirancang dengan tutup dari jaring dan diberi resleting dan diberi pemberat dibawahnya agar mudah dibawa ke dasar laut oleh nelayan. Ember dekompresi digunakan untuk tempat mengumpulkan ikan hasil tangkapan sebelum dibungkus kedalam plastik dan 
diberi oksigen. Alat tangkap merupakan alat ukur penting dalam praktek perikanan.

3. setelah proses penangkapan, kemudian nelayan mengubah perlakuan ikan pasca penangkapan. Sebelum pendampingan dilakukan, nelayan kurang memperhatikan proses perlakuan ikan pasca penangkapan, sehingga kualitas ikan hias yang ditangkap oleh nelayan menjadi buruk, disamping efek dari penggunaan sianida. Penanganan ikan pascatangkap merupakan proses penting dalam perdagangan ikan hias ramah lingkungan. Proses penyortiran, pengepakan, dan pemisahan ini dilakukan oleh nelayan dan pengepul ikan hias Desa Les setelah pendampingan. Hasil tangkapan nelayan kemudian dikumpulkan oleh pengepul yang kemudian diperiksa jumlah dan kualitasnya. Pengepul akan membayar nelayan sesuai harga yang telah disepakati bersama (sesuai harga pasar ditingkat pengepul), kemudian dilakukan penyortiran, pengepakan, dan pemisahan sebagai kegiatan pascatangkap.

Dalam Pedoman Panduan Penanganan Ikan Hias Pasca Penangkapan yang diterbitkan oleh Yayasan Alam Indonesia Lestari (LINI) pada tahun 2008, penyortiran dilakukan dengan tujuan untuk membuang ikan yang sudah mati, memisahkan ikan rejekan (yang tidak sesuai standar pemasaran) agar dapat dikembalikan ke laut, menurunkan tingkat kematian ikan, dan mengurangi pengepakan yang tidak perlu. Pengepakan baru dilakukan setelah menerima order dari eksportir. Pengepakan dilakukan berdasarkan ukuran dan jenis ikan, ukuran ikan yang kecil dipak dengan plastik yang agak besar dengan 50\% diisi air laut dengan salinitas bagus dan $50 \%$ oleh oksigen. Proses penanganan pascatangkap yang terakhir adalah oleh pemisahan atau segrasi. Pemisahan dilakukan untuk memastikan dan menjamin kualitas ikan tetap tinggi. Pemisahan ini dilakukan disetiap proses mulai dari nelayan, pengepul, eksportir hingga pembeli terakhir. Dengan dilakukannya segresi ini maka akan mudah ditelusuri lokasi tangkapnya, pelaku penangkapannya. Penelusuran inilah yang akan membuktikan kualitas ikan yang terbaik.

4. Sejalan dengan perubahan penanganan pasca penangkapan yang dilakukan oleh nelayan dan pengepul, perlakua eksportir juga berubah. Eksportir menerima ikan-ikan hias dari pengepul dari seluruh Bali untuk kemudian diekspor ke luar negeri. Ikan-ikan hasil tangkapan ramah lingkungan ini memiliki nilai lebih daripada ikan-ikan hasil tangkapan tidak ramah lingkungan. Ikan menjadi lebih sehat dan lebih kuat. Kondisi fisik ikan dan permintaan importir akan ikan yang ramah lingkungan membuat eksportir menyukai ikan-ikan dari Desa Les. Eksportir turut melakukan aktivitas pemisahan (segregasi) ikan agar dapat ditelusuri sumber dan kualitasnya.

Pemakaian sianida akan menyebabkan gerakan ikan kacau. Pemakaian sianida dapat menyerang liver dari oragnisme yang akan mengakibatkan ikan mati kelaparan atau mengalami kerusakan pada organ dalam (LINI, 2008). Pemakaian sianida mulai diadopsi oleh nelayan ikan hias pada tahuan 1986. Setelah 15 tahun nelayan baru menyadari bahwa tindakan mereka telah merusak sumber daya alam yang merupakan sumber mata pencaharian utama nelayan. Sumber daya alam yang rusak, antara lain terumbu karang dan ikan hias. Terumbu karang merupakan tempat berkembangbiaknya sebagian besar ikan, terutama ikan hias. Menurut Yap (2000) dalam Fox et al. (2005), terumbu karang adalah habitat yang paling kompleks untuk direstorasi.

Berdasarkan hasil monitoring yang dilakukan oleh Yayasan Bahtera Nusantara tahun 1999 telah terjadi degradasi lingkungan yang cukup parah akibat praktek perikanan yang merusak. Untuk menanggulangi masalah ekologis ini, LSM bersama masyarakat pesisir Desa Les melakukan rehabilitasi karang. Tehnik dalam merestorasi karang dapat dilakukan tranpalantasi karang atau membuat taman karang di bawah laut (Rinkevich, 2000 dalam Fox et al., 2005). Rehabilitasi karang Desa Les dilakukakan dengan cara transplantasi karang dengan menggunakan terumbu karang buatan (artificial reef). Terumbu buatan adalah ekosistem yang tersusun dari struktur benda-benda keras yang diletakkan di pasar perairan yang tidak produktif, dengan sifat-sifat yang berbeda satu sama lain (Yahya, 2011). Bentuk terumbu buatan yang diperkenalkan oleh LSM kepada nelayan Desa Les antar lain berbentuk roti buaya, meja besi, dan hexadome. Rehabilitasi karang dilakukan bersama masyarakat mereka merestorasi karang dengan cara menyetek karang yang masih hidup lalu diletakkan pada substrat buatan. Yahya et al. (2006) dalam Laporan Pengelolaan Perikanan Tejakula menyebutkan bahwa wilayah rehabilitasi karang Desa Les adalah seluas 200 $\mathrm{m}^{2}$ dan ditetapkan sebagai daerah bebas tangkap (no-take zone) yang disahkan oleh pemerintah desa.

Luas persentase tutupan karang setelah dilakukannya rehabilitasi karang mulai tahun 2002 hingga 2007 mengalami peningkatan baik karang pada kedalaman tiga meter maupun tujuh meter. Gambar 4 merupakan diagram yang menggambarkan hasil monitoring Yayasan Bahtera Nusantara selama lima tahun di perairan Desa Les. Life coral atau terumbu karang yang hidup mengalami peningkatan walaupun pada grafik menunjukkan ada periode naik turun. Pertumbuhan karang memperluas tutupan karang di perairan membentuk pola sepeti gelombang namun terus naik. Pertumbuhan karang mengalami korelasi yang positif dengan peningkatan jumlah stok ikan keberlimpahan ikan. Tidak ada data konkrit mengenai keberlimpahan ikan, sehingga yang menjadi parameter adalah pengakuan nelayan atas kembali adanya ikan-ikan jenis tertentu yang telah jarang di perairan Desa Les. 


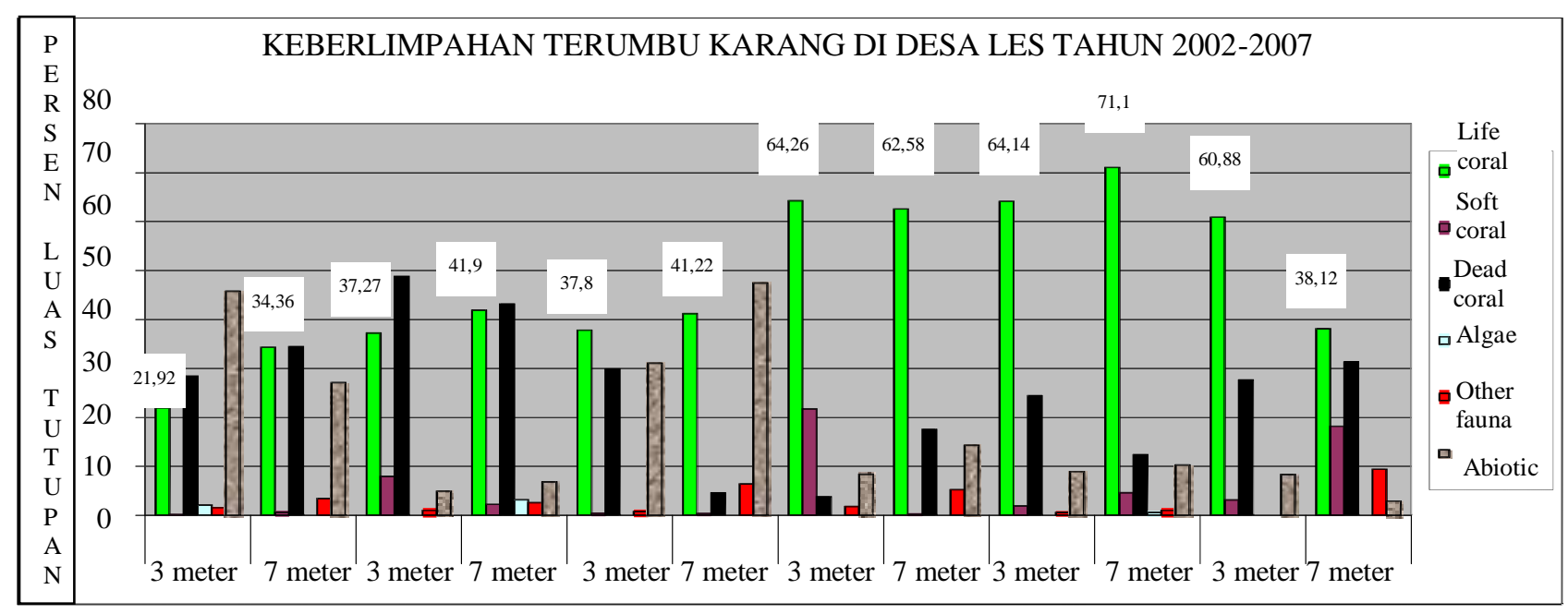

Gambar 4. Diagram Keberlimpahan Terumbu Karang di Desa Les Tahun 2002-2007

Selain merehabilitasi karang, untuk mengembalikan dan menjaga kondisi ekologis perairan Desa Les dilakukan pelatihan menangkap ikan dengan ramah lingkungan. Pelatihan dilakukan baik untuk penangkapan ikan di perairan dangkal (maksimal kedalaman lima meter) maupun penangkapan di perairan dalam (kedalaman lima sampai 40 meter). Pelatihan yang diberikan adalah berupa pelatihan selam, bagaimana bernafas yang benar saat menyelam dengan atau tanpa alat bantu pernapasan, kompresor. Pelatihan menangkap ikan ramah lingkungan dengan menggunakan jaring penghalang dan serok. Nelayan juga dilatih untuk membuat jaring dan serok sendiri. Peningkatan kapasitas kelompok nelayan dengan membentuk kelompok nelayan ikan hias Mina Bhakti Soansari.

Perubahan yang telah dilakukan tidak akan berarti apabila tidak ada pengawasan bersama. Dalam konteks Desa Les, pengawasan praktek perikanan ramah lingkungan dilakukan bersama-sama dan didasari oleh peraturan adat, awig-awig. Pelanggaran yang dilakukan oleh pihak-pihak tertentu akan dijatuhi hokum adat. Praktek perikanan ramah lingkungan di Desa Les sudah menginternalisasi dalam nelayan. Tidak hanya dikaitkan dengan hukum adat. Praktek perikanan ramah lingkungan juga dianggap sebagi salah satu bentuk penghormatan dan terima kasih nelayan yang mayoritas beragama Hindu kepada Hyang Widhi (Sang Pencipta bagi penganut agama hindu). Kesuksesan LSM pendamping dalam program perikanan ikan hias ramah lingkungan di Desa Les dapat dikatakan berhasil. Perubahan pola pikir yang mendasar oleh nelayan merupakan salah satu parameter keberhasilan ini. Proses pembelajaran yang dilakukan nelayan Desa Les dapat dikategorikan proses pembelajaran yang double loop learning atau pembelajaran ganda. Terdapat tiga jenis pembelajaran, yaitu single loop learning, double loop learning, dan triple loop learning (Frey, 2011). Hasil pembelajaran dari single loop learning adalah terjadi perubahan untuk memenuhi atau memperbaiki lingkungan dan melestarikan keanekargaman hayati serta untuk meningkatkan pendapatan (Armitage et al., 2008). Namun pada pembelajaran jenis ini tidak terjadi perubahan mendasar pada norma dan kepercayaan masyarakat dan tidak terjadi perubahan kebiasaan pemangku kepentingan (stakeholders).

Proses pembelajaran nelayan ikan hias Desa Les terhadap praktek perikanan ramah lingkungan, seperti yang telah dijelaskan sebelumnya, telah memperbaiki keanekaragaman hayati serta stabilisasi pendapatan nelayan. Bagian terpenting dalam pembelajaran di Desa Les adalah terjadi perubahan norma dan kepercayaan masyarakat serta merubah perilaku nelayan. Partisipasi nelayan dalam perubahan menguatkan pembelajaran ini menyebabkan perubahan mendasar pada perilaku (Berkes, 2009 dalam Frey, 2011). Armitage et al. (2008) merumuskan kerangka kelembagaan dan organisasi yang merealisasikan pembelajaran putaran ganda, adanya upaya membangun kepercayaan, berani mengambil resiko dalam memperluas kesempatan belajar, perlunya transparansi untuk menguji nilai-nilai yang tertanam, keterlibatan aktif dalam masyarakat, dan tingginya tingkat partisipasi masyarakat.

Upaya membangun kepercayaan diri nelayan Desa Les yang telah mengambil resiko untuk merubah pola tangkap ikan hias mereka. Resiko menurunnya pendapatan dimasa transisi diambil nelayan agar terjadi proses belajar yang menyeluruh. Pengawasan praktek perikanan ramah lingkungan yang dilakukan secara bersama-sama menuntut keterbukaan dan keterlibatan aktif para nelayan. Hal tersebut memperlihatkan partisipasi nelayan yang tinggi dalam pelaksanaan perikanan ramah lingkungan. Sampai pada tahap ini, nelayan ikan hias Desa Les telah mulai me-rasakan perubahan yang berarti terhadap kondisi lingkungan laut Les. Diversikasi alat tangkap dilakukan oleh nelayan Les adalah untuk melakukan penangkapan yang ramah lingkungan dan bertanggung jawab. Diversifikasi ini selain untuk melestarikan alam juga untuk menaikkan taraf ekonomi nelayan. Dengan menggunakan alat yang ramah lingkungan maka keberlimpahan ikan akan tetap terjaga, dan nelayan dapat menangkap ikan dengan stabil. Kestabilan ini juga akan 
mengakibatkan kestabilan perekonomian nelayan. Diversifikasi alat tangkap tentulah melalui proses adopsi inovasi.

Adopsi inovasi yang terjadi setelah perubahan sistem sosial masyarakat nelayan Desa Les adalah dalam penggunaan kembali alat tangkap tradisional yang ramah lingkungan, jaring peng-halang (barrier net) dan serok (scoopnet). Masyarakat nelayan Les kemudian melakukan proses ini, dan meng-internalisasi hasilnya kedalam nilainilai kehidupan sehari-hari. Secara umum nelayan merupakan subjek utama dalam perikanan ramah lingkungan dalam rangka mewujudkan perikanan yang berkelanjutan. Akan tetapi tidak mungkin apabila nelayan berdiri sendiri tanpa bantuan dari berbagai pemangku kepentingan.

Stakeholder (pemangku kepentingan) didefinisikan oleh Sukada (2007) sebagai individu yang memiliki kepentingan atas dasar keputusannya sendiri baik sebagai presentatif individu maupun kelompok. Berdasarkan hasil identifikasi, masing-masing pemangku kepentingan memiliki peran yang berbeda pada setiap level partisipasi. Praktek perikanan ramah lingkungan ini melewati empat tahap, yakni tahap perencanaan, tahap implementasi, dan tahap evaluasi, dan tahap pertanggungjawaban.

Nasdian (2006) menyatakan "Empowerment is a way or means to participation" (pemberdayaan adalah jalan untuk menuju partisipasi). Partisipasi didefinisikan sebagai suatu proses aktif yang ini yang inisiatifnya diperoleh oleh masyarakat sendiri, dengan pemikiran masyarakat sendiri, dengan menggunakan lembaga dan mekanisme untuk menegaskan kontrol yang efektif. Partisipasi komunitas identik dengan kekuatan komunitas (citizen participation is citizen power). Implementasi praktek perikanan ramah lingkungan di Desa Les telah melalui tangga partisipasi seperti yang tertera pada tabel sebelumnya.

Tabel 3 menjelaskan partisipasi dean peran pemangku kepentingan dalam program PRL di Desa Les. Salah satu bentuk partisipasi dalam pelaksanaan perikanan ramah lingkungan di Desa Les adalah keikutsertaan nelayan dalam kelompok nelayan ikan hias Mina Bhakti Soansari. Keikutsertaan adalah salah satu bentuk partisipasi yang diukur secara kuantitatif dalam penelitian ini. Tingkat penddikan dan tingkat pengalaman nelayan dalam melakukan penangkapan ikan diduga memiliki kaitan dengan keikutsertaan nelayan.

Tingkat keikutsertaan dalam kelompok akan menunjukkan seberapa sering interaksi yang nelayan lakukan dengan kelompok. Sehubungan dengan kelompok nelayanlah yang menjadi sentra perubahan demi perubahan dalam praktek perikanan. Pertukaran ilmu pengetahuan, informasi, dan hal lainnya terjadi di kelompok. Penting untuk mengukur tingkat keikutsertaan dalam kelompok. Diukur dari seberapa banyak kehadiran nelayan dalam pertemuan kelompok yang diadakan setiap setelah upacara adat tumpek setiap 35 hari sekali.
Tabel 3. Matriks Partisipasi dan Peran Pemangku Kepentingan dalam Program Perkinanan Ramah Lingkungan

\begin{tabular}{|c|c|c|c|}
\hline $\begin{array}{c}\text { Tahap } \\
\text { implementasi }\end{array}$ & $\begin{array}{c}\text { Stakeholders } \\
\text { terkait }\end{array}$ & Peran stakeholders & $\begin{array}{c}\text { Tingkat } \\
\text { partisipasi }\end{array}$ \\
\hline \multirow[t]{3}{*}{ Perencanaan } & $\begin{array}{l}\text { Lembaga } \\
\text { Swadaya } \\
\text { Masyarakat } \\
\text { (LSM) }\end{array}$ & $\begin{array}{l}\text { Inisiator program } \\
\text { perubahan pola praktek } \\
\text { penangkapan ikan } \\
\text { nelayan yang merusak } \\
\text { untuk menjadi lebih } \\
\text { ramah lingkungan. } \\
\text { Perencanaan dan } \\
\text { memberikan informasi } \\
\text { dan p engetahuan kepada } \\
\text { nelayan }\end{array}$ & \multirow[t]{2}{*}{ Konsultasi } \\
\hline & Nelayan & $\begin{array}{l}\text { Berpartisipasi dalam } \\
\text { FGD, tetapi tidak } \\
\text { menjadi pengambil } \\
\text { keputusan }\end{array}$ & \\
\hline & $\begin{array}{l}\text { Pemerintah } \\
\text { Desa Les }\end{array}$ & Tidak berkaitan & $\begin{array}{c}\text { Tidak } \\
\text { berpartisipasi }\end{array}$ \\
\hline \multirow[t]{3}{*}{ Implementasi } & LSM & $\begin{array}{l}\text { Memberikan bantuan } \\
\text { kepada seluruh proses, } \\
\text { mulai dengan } \\
\text { meningkatkan kesadaran } \\
\text { nelayan, merehabilitasi } \\
\text { terumbu karang, dan } \\
\text { memperkenalkan cara } \\
\text { menangkap baru yang } \\
\text { lebih ramah lingkungan }\end{array}$ & \multirow[t]{2}{*}{ Kemitraan } \\
\hline & Nelayan & $\begin{array}{l}\text { Membuat perubahan pada } \\
\text { pola dan peralatan } \\
\text { memancing yang } \\
\text { digunakan untuk } \\
\text { menagkap ikan, } \\
\text { rehabilitasi terumbu } \\
\text { karang, setelah pelatihan }\end{array}$ & \\
\hline & $\begin{array}{l}\text { Keluarga } \\
\text { nelayan }\end{array}$ & $\begin{array}{l}\text { Terlibat langsung hanya } \\
\text { pada program rehabilitasi } \\
\text { terumbu karang }\end{array}$ & Terapi \\
\hline \multirow[t]{3}{*}{ Evaluation } & LSM & $\begin{array}{l}\text { Pada tahap ini, LSM yang } \\
\text { terlibat langsung dalam } \\
\text { proses evaluasi sejauh } \\
\text { mana prestasi telah } \\
\text { dicapai oleh nelayan } \\
\text { untuk mengubah pola } \\
\text { memancing }\end{array}$ & \multirow[t]{2}{*}{$\begin{array}{c}\text { Pendelegasian } \\
\text { kekuatan }\end{array}$} \\
\hline & Nelayan & $\begin{array}{l}\text { Nelayan yang terlibat } \\
\text { dalam proses evaluasi. } \\
\text { LSM membantu para } \\
\text { nelayan untuk menilai } \\
\text { kinerja mereka sendiri }\end{array}$ & \\
\hline & $\begin{array}{l}\text { Pemerintah } \\
\text { Desa Les }\end{array}$ & $\begin{array}{l}\text { Sebatas mengetahui } \\
\text { tetapi tidak terkait } \\
\text { dalam evaluasi }\end{array}$ & Manipulatif \\
\hline \multirow[t]{3}{*}{$\begin{array}{l}\text { Pertanggung- } \\
\text { jawaban }\end{array}$} & LSM & $\begin{array}{l}\text { Menerima laporan dari } \\
\text { nelayan }\end{array}$ & \\
\hline & Nelayan & $\begin{array}{l}\text { Dalam hal ini hanya } \\
\text { kelompok administrator } \\
\text { yang terlibat dalam } \\
\text { pelaporan, tetapi semua } \\
\text { anggota kelompok } \\
\text { mengetahui }\end{array}$ & $\begin{array}{c}\text { Kontrol } \\
\text { masyarakat }\end{array}$ \\
\hline & $\begin{array}{l}\text { Pemerintah } \\
\text { Desa Les }\end{array}$ & Tidak terkait & $\begin{array}{c}\text { Tidak } \\
\text { berpartisipasi }\end{array}$ \\
\hline
\end{tabular}




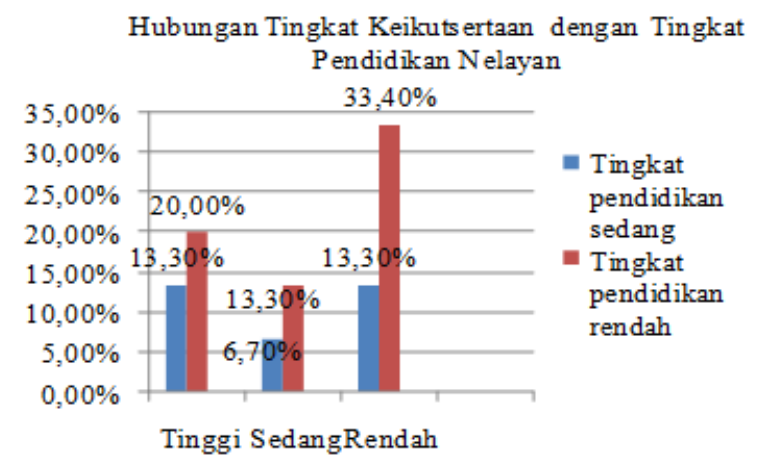

Gambar 5. Hubungan Tingkat Keikutsertaan dan Tingkat Pendidikan

Gambar 5 memperlihatkan tidak adanya nelayan yang berpendidikan tinggi (tamat SMA/sederajat) di Desa Les. Tingkat keikutsertaan dalam kelompok yang tertinggi adalah nelayan yang berpendidikan rendah (tidak tamat SD/tamat SD sederajat), yaitu sebanyak $20 \%$. Begitu pula dengan tingkat partisipasi kelompok terendah juga pada nelayan yang bertingkat pendidikan rendah sebanyak $33,40 \%$. Para nelayan yang berpendidikan sedang (tamat SMP/sederajat) menunjukkan angka yang sama sekitar $13,30 \%$ pada tingkat partisipasi kelompok yang rendah dan tinggi.

Di sini terlihat bahwa tingkat pendidikan nelayan tidak memiliki korelasi yang positif terhadap tingkat keikutsertaan neyalan dalam kelompok nelayan. Jumlah nelayan yang berpendidikan rendah cukup tinggi di Desa Les, sehingga hal ini bukan merupakan ukruan yang tepat untuk mengukur keikutsertaan dalam kelompok. Keikutsertaan dalam kelompok tinggi, karena kebutuhan nelayan yang tinggi untuk berinteraksi, bertukar informasi mengenai masalah penangkapan dan hal-hal lainnya. Ikatan kekeluargaan juga termasuk ke dalam faktor yang membuat tingkat keikutsertaan tinggi.

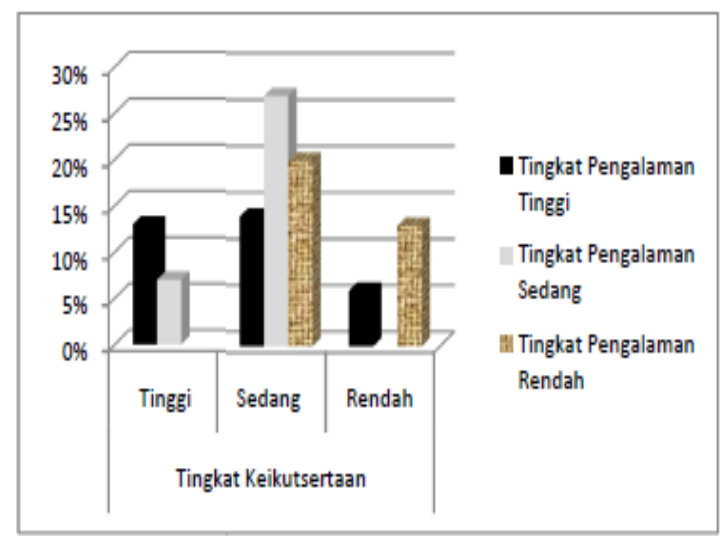

Gambar 6.Hubungan Tingkat Keikutsertaan dengan Tingkat Pengalaman Kerja

Tingkat keikutsertaan dalam kelompok nelayan diduga dipengaruhi oleh tingginya tingkat pengalaman nelayan dalam profesinya. Gambar 6 menunjukkan pola tingkat pengalaman nelayan dan tingkat keikutsertaannya. Pada Gambar 6 terlihat bahwa $61 \%$ nelayan memiliki tingkat keikutsertaan sedang. Hal ini menunjukkan bahwa sebagian besar nelayan hanya hadir kurang dari delapan kali dalam setahun untuk mengikuti pertemuan rutin kelompok nelayan. Nelayan dengan tingkat pengalaman kerja tinggi sebanyak 34\% memiliki tingkat keikutsertaan dalam kelompok yang beragam. Tingkat keikutsertaan yang tinggi tidak hanya dipengaruhi oleh tingkat pengalaman kerja, melainkan faktor lainnya.

Tingkat keikutsertaan dalam penelitian ini adalah bagian dari wujud partisipasi nelayan dalam mewujudkan perikanan yang berkelanjutan. Partisipasi menurut Arstein (1969) memiliki delapan tangga partisipasi yang menggambarkan gradasi kekuasaan yang bertingkat dalam pengambilan keputusan. Setiap anak tangga dari delapan anak tangga didasarkan oleh pola distribusi kekuasaan. Tingkat keikutsertaan dalam kelompok yang diukur secara kuantitatif, seperti di atas, sesungguhnya ingin menggambarkan partisipasi yang dilakukan oleh nelayan dalam mewujudkan perikanan yang berkelanjutan.

Tangga pertama dan kedua dalam tangga partisipasi Arstein, manipulation (manipulatif) dan therapy (terapi) tidak dapat dikategorikan partisipatif, karena tidak ada partisipasi disini. Masyarakat tidak dapat turut berpartisipasi dalam merencanakan dan merumuskan program, penggagas partisipasi hanya mengajarkan sehingga terlihat seolah partisipatif. Pada tangga selanjutnya berurut partisipasi dalam bentuk informing (pemberitahuan), consultation (konsultasi), dan placation (penetraman). Ketiga tangga ini bersifat tokenisme, masyarakat dapat bersuara hanya untuk menyetujui. Suara masyarakat memiliki hak untuk didengar dan mendengar, namun keputusan tetap berada di tangan penguasa.

Tiga tangga selanjutnya, partnership (kemitraan), delegated power (pendelagasian kekuasaan), dan citizen control (kontrol masyarakat). Pada tangga kemitraan memungkinkan masyarakat untuk bernegosiasi dan memutuskan suatu hal dengan ada timbal baliknya dengan pemegang kekuasaan. Sementara pada pendelegasian kekuasaan, nelayan telah memiliki kekuasaan sebagian atau keseluruhan program. Sementara pada kontrol masyarakat, masyarakat telah memiliki kekuasaan penuh utnuk mengatur semuanya. Disinilah puncak partisipasi masyarakat dalam tangga Arstein. Pembeda dari kedelapan anak tangga ini adalah distribudi kekuasaan dari yang berkuasa (powerfull) kepada yang tidak memiliki kuasa (powerless).

Pelaksanaan perikanan ikan hias berkelanjutan di Desa Les, telah melalui tahapan-tahapan partisipasi, seperti yang telah dipaparkan sebelumnya. Dalam penelitian ini partisipasi diukur dengan cara kualitatif, dengan observasi langsung dan wawancara pihak-pihak berkepentingan terkait. Saat ini, partisipasi yang dilakukan oleh nelayan ikan hias khususnya telah menempati tangga tertinggi, yakni citizen control. Dalam Rosyida (2010), citizen control ini merupakan salah satu bentuk pengawasan komunitas yang terbentuk independensi dan monitoring 
komunitas lokal. Masyarakat sepenuhnya mengelola berbagai kegiatannya yang telah disepakati bersama tanpa campur tangan penyelenggara program.

Hipotesis penelitian ini menyatakan hubungan semakin tinggi pengalaman kerja maka semakin tinggi pula tingkat pendapatan yang dihasilkan oleh nelayan. Tingkat pendapatan diklasifikasikan rendah jika berada dibawah penghasilan rata-rata keseluruhan responden, sedang bila berada ditengah penghasilan rata-rata responden, dan tinggi bila diatas rata-rata penghasilan responden. Adapun penghasilan rata-rata responden adalah sekitar Rp1.200.000,00 (satu juta dua ratus ribu rupiah).

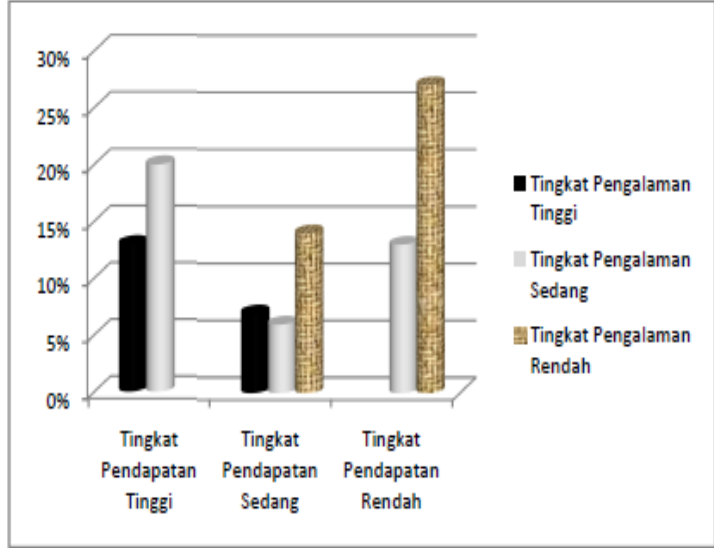

Gambar 7. Hubungan Tingkat Pendapatan dan Tingkat Pengalaman Kerja

Gambar 7 menunjukkan tingkat pengalaman tinggi memiliki hubungan dengan tingkat pengalaman kerja. Semakin tinggi tingkat pengalaman kerja maka semakin tinggi pula tingkat pendapatannya. Hal ini disebabkan kemapuan, serta keahlian dalam menangkap ikan yang telah teruji. Tingkat pengalaman rendah memperjelas hubungannya dengan pendapatan yang rendah pula.

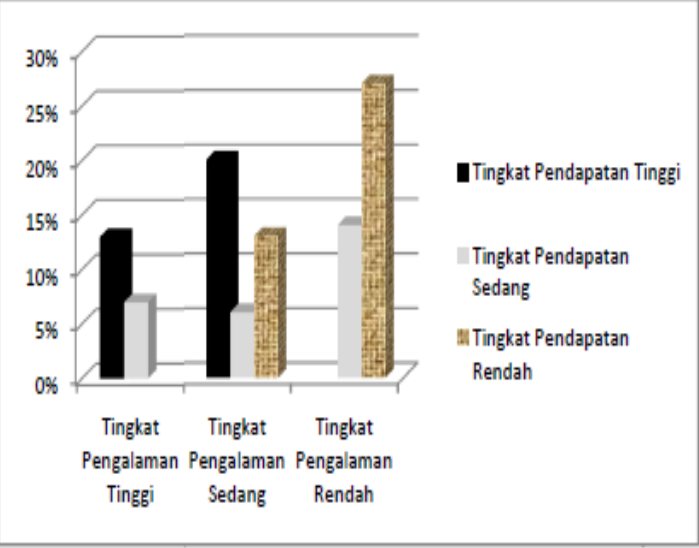

Gambar 8. Hubungan Tingkat Pendapatan dan Tingkat Pengalaman Nelayan Ikan Hias

Perikanan berkelanjutan seharusnya memberi jaminan kepada para nelayan agar stabilisasi ekonomi mereka dapat terjadi. Dengan pendapatan yang stabil perikanan berkelanjutan dapat menjadi berkembang. Tingkat pendapatan nelayan yang tinggi tidak ditentukan oleh tingginya tingkat pengalaman. Namun sebagian besar nelayan yang memilki tingkat pendapatan rendah adalah nelayan hanya memiliki tingkat pengalaman bekerja di bawah lima tahun.

PRL (ecolabelling) merupakan pemberian label pada produk sebagai penyedia informasi bagi konsumen untuk menunjukkan perhatiannya terhadap lingkungan untuk menciptakan insentif berbasis pasar demi pengelolaan perikanan yang lebih baik (Gardiner Visnawathan, 2004; Nunes dan Riyanto, 2005; FAO, 2007; Wynne, 1994; Leubuscher, 1998 dalam Ibanez et al., 2008). PRL adalah sebuah instrumen pasar untuk memenuhi kebutuhan 'green consumer' (konsumen yang sadar lingkungan) untuk pemasaran di pasar internasional. Pada dasarnya PRL sejalan dengan konsep fair trade (perdangan yang adil), namun kenyataan di lapang, dalam tulisan ini di Desa Les, Bali, perdagangan yang adil tidak terjadi. Hal ini akan dipaparkan pada subbab selanjutnya.

PRL dilakukan oleh eksportir sebagai pihak yang mendistribusikan ikan hias ke pihak importir. Nelayan pada posisi penangkap ikan hias yang menangkap ikan sesuai dengan orderan (permintaan) dari pihak pengepul. Informasi yang dimiliki nelayan mengenai pelabelan lingkungan maupun harga jual ikan terbatas sampai tingkat pengepul. Setelah ikan hasil tangkapan disetorkan kepada pengepul, nelayan mendapatkan upah. Nelayan tidak mengetahui apa yang terjadi pada rantai perdagangan berikutnya. PRL merupakan sertifikat yang diberikan oleh lembaga sertifikasi kepada para mata rantai perdagangan ikan hias. Sertifikat ini diberikan kepada para nelayan, pengepul, dan eksportir. Pemegang sertifikat ini sudah seharusnya menerapkan standar operasional yang ditetapkan MAC untuk mendapatkan hasil produk yang ramah lingkungan dan dapat diberi label, ekolabel.

PRL sebenarnya adalah perkawinan antara permintaan pasar (ekonomi) dan ekologi dalam segitiga antara ekologi, ekonomi, dan sosial. Sementara itu untuk mendukung keberhasilan PRL dibutuhkan kekuatan sosialekologi berupa insentif. Insentif diperlukan agar memperkuat motif ekonomi yang membuat aktor tetap menjalankan PRL. PRL, secara filosofis merupakan upaya untuk mengurangi eksternalitas negatif dalam kegiatan eksplorasi sumber daya alam. Eksternalitas sendiri merupakan efek yang ditimbulkan dari proses produksi dan dapat bernilai positif maupun negatif (Sankar, 2011). Eksternalitas negatif ini biasa disebut sebagai polusi, sedangkan yang menyebabkan polusi terjadi adalah poluter (polluter). Perikanan ikan hias Les, memperoleh eksternalitas negatif atas praktek perikanan yang eksploratif dan merusak akibat penggunaan sianida. Terumbu karang rusak, keberagaman ikan hias menurun, serta keberlimpahan ikan juga menurun drastis merupakan beberapa bentuk polusi yang terjadi di Les. Sebagai poluter, nelayan ikan hias sudah seharusnya melakukan perbaikan. Pada kasus nelayan ikan hias Les, para nelayan telah mulai melakukan pengurangan eksternalitas negatif 
yang ditimbulkan sejak tahun 2000, sebagai bentuk pertanggungjawaban sosial melayan kepada laut. MAC sebagai lembaga sertifikasi, mulai mensertifikasi mata rantai perdagangan ikan hias Les pada tahun 2005. Pada tahun 2006, hasil tangkapan nelayan ikan hias Les telah memperoleh PRL.

PRL mulai dilakukan di Desa Les pada tahun 2006 oleh lembaga sertifikasi MAC Indonesia. Pada akhir tahun 2005 MAC menilai bahwa praktek perikanan ramah lingkungan yang telah diterapkan oleh para nelayan ikan hias Les telah baik. Hasil tangkapan para nelayan Les yang ramah lingkungan akan bernilai tinggi dengan adanya PRL dari MAC. Hasil tangkapan dengan PRL ini akan dapat dengan mudah menembus pasar perdagangan ikan hias internasional dan memiliki harga yang lebih tinggi dibandingkan dengan hasil tangkapan yang tidak ramah lingkungan. Tidak semua nelayan ikan hias Les yang tersertifikasi ramah lingkungan. Ada aspek penilaian yang tidak dapat dipenuhi sehingga beberapa nelayan tidak tersertifikasi, begitu juga dengan eksportir dan para pengepul. PRL diberikan kepada ikan hasil tangkapan nelayan yang bersertifikat ramah lingkungan saja. Namun pada prakteknya seluruh ikan hasil tangkapan nelayan ikan hias Les, diterima dan diperdagangkan. Alasannya karena seluruh nelayan ikan hias Les meski tidak tersertifikasi telah memiliki kemampuan yang sama dalam menangkap ikan dengan ramah lingkungan. Pada akhirnya seluruh ikan hias hasil tangkapan nelayan Les mendapat sertifikat PRL.

Harga ikan hias pada tingkat pengepul di Desa Les tidak berubah menjadi lebih tinggi seperti yang dijanjikan oleh PRL sebelumnya. Harga ikan hias ditingkat eksportir juga tidak mengalami perubahan. Dalam hal ini pengepul dan eksportir tidak berdaya oleh kekuasaan pasar yang memberi harga yang tidak membedakan ikan hias hasil PRL maupun yang tidak. Namun, karena permintaan yang tinggi dan stabil dari pasar internasional membuat para eksportir tetap memenuhi permintaan pasar. Umumnya, di Indonesia tidak ada perbedaan harga ikan hias hasil tangkapan ramah lingkungan dan yang tidak ramah lingkungan. Tidak ada insentif yang diberikan kepada pelaku pasar yang ramah lingkungan. Ada dua pendapat mengenai praktek ekolabeling di Desa Les, pihak LSM menyatakan bahwa sebenarnya sistem PRL belum berjalan meski para mata rantai perdagangannnya telah disertifikasi oleh pihak MAC. Di lain pihak MAC Indonesia menyatakan program sertifikasi telah berjalan dengan baik, karena sebenarnya yang menjadi tujuan utama pada program ini adalah sertifikasi ramah lingkungan. Berjalan atau tidaknya para pemegang peranan perdagangan ikan hias kurang menjadi perhatian. Terlebih setelah sertifikasi ini kadaluarsa pada tahun 2008. Program oleh MAC ini tidak berlanjut, oleh karena MAC sebagai lembaga sertifikasi kolaps kekurangan dana.
Tabel 4. Peran Pemangku Kepentingan Perdagangan Ikan Hias

\begin{tabular}{|c|c|c|}
\hline No. & $\begin{array}{c}\text { Pemangku } \\
\text { kepentingan } \\
\text { perdagangan }\end{array}$ & Peran \\
\hline 1. & $\begin{array}{l}\text { Nelayan ikan } \\
\text { hias } \\
\text { (ornamentalfish } \\
\text { fisherman) }\end{array}$ & $\begin{array}{l}\text { Nelayan ikan hias merupakan tonggak } \\
\text { utama pada mata rantai perdagangan } \\
\text { ikan hias ramah lingkungan. Oleh } \\
\text { karena nelayanlah bersinggungan } \\
\text { langsung dengan alam. Cara nelayan } \\
\text { menangkap, memperlakukan ikan, dan } \\
\text { membungkus ikan sesuai dengan } \\
\text { kriteria yang ditentukan. Apabila } \\
\text { nelayan mengabaikan ini, maka per- } \\
\text { dagangan ikan hias ini tidak dapat } \\
\text { dikatakan sebagai perikanan yang } \\
\text { ramah lingkungan. Sistem ekolabeling } \\
\text { tidak berialan }\end{array}$ \\
\hline 2. & $\begin{array}{l}\text { Pengepul } \\
\text { (middleman) }\end{array}$ & $\begin{array}{l}\text { Ikan-ikan hasil tangkapan nelayan } \\
\text { dikumpulkan kepada pengepul yang } \\
\text { juga telah tersertifikasi, sehingga ikan- } \\
\text { ikan tersebut di-repackage juga } \\
\text { dengan kriteria ramah ling-kungan. } \\
\text { Pengepullah yang akan mendistribusi- } \\
\text { kan hasil tangkapan nelayan ini ke } \\
\text { eksportir yang ada di Denpasar }\end{array}$ \\
\hline 3. & Eksportir & $\begin{array}{l}\text { Merupakan pemangku kepentingan } \\
\text { yang biasanya beradadi kota, eksportir } \\
\text { juga memegang peranan penting pada } \\
\text { rantai perdagangan ikan hias karena } \\
\text { berada di garis terluar rantai per- } \\
\text { dagangan internasional di dalam } \\
\text { negeri. Eksportir menampung semua } \\
\text { ikan-ikan dari pengepul. Bagi } \\
\text { eksportir yang tersertifikasi seharus- } \\
\text { nya hanya mengumpulkan dan me- } \\
\text { nyalurkan ikan hasil tangkapan ramah } \\
\text { lingkungan yang telah tersertifikasi }\end{array}$ \\
\hline 4. & Importir & $\begin{array}{l}\text { Merupakan pihak asing atau pihak } \\
\text { pembeli yang berada di luar negeri } \\
\text { yang membeli ikan hasil penangkapan } \\
\text { ramah lingkungan yang telah } \\
\text { tersertifikasi MAC }\end{array}$ \\
\hline
\end{tabular}

MAC merupakan pihak kedua dalam mensertifikasi, sehingga apabila dikaitkan dengan skema PRL yang dirumuskan oleh Gardiner dan Visnawathan (2004) ini termasuk kepada skema PRL jenis ketiga. Pada skema ekolabeling jenis ketiga, pensertifikasian dilakukan atau dinilai oleh pihak ketiga yang digagas oleh pihak kedua untuk pihak pertama. Dalam kasus ini pihak pertama adalah nelayan ikan hias Desa Les, sedangkan pihak keduanya adalah MAC. MAC membayar pihak ketiga untuk menilai kecakapan serta kemampuan pihak pertama, sehingga penilaian yang diberikan adil (fair). Adapun beberapa pihak yang MAC sertifikasi di Desa Les beserta perannya dijabarkan pada Tabel 4. Apabila ke-empat pemegang peranan ini menjalankan perannya masing-masing dengan benar maka PRL di Indonesia khususnya untuk perikanan ikan hias akan berjalan.

Berikut akan dipaparkan dampak yang ditimbulkan dari pelaksaan sertifikasi selama dua tahun bagi masyarakat 
nelayan Desa Les. Dampak akan dibagi ke dalam beberapa bidang. Perlu digarisbawahi yang berlangsung di Desa Les selama periode dua tahun (2006-2008) adalah sertifikasi ramah lingkungan oleh MAC sebagai langkah perwujudan sistem PRL. Di mana PRL merupakan sebuah instrumen pasar dalam perdagangan ikan hias internasional. Di bawah dirumuskan dampak dari pelaksaan sertifikasi ramah lingkungan bersama para nelayan ikan hias yang pernah tersertifikasi oleh MAC:

1. Dampak sosial merupakan dampak yang dihasilkan dari perjalanan proses pensertifikasian para mata rantai perdagangan ikan hias. Diantaranya dampak sosial yang terekam:

a. konflik laten perbedaan pandang antara LSM yang mempelopori perikanan ramah lingkungan dengan Lembaga Seritifikasi yang menginisiasikan sertifikasi. Dalam kasus ini adalah LSM Telapak dan Yayasan Bahtera Nusantara dengan Marine Aquarium Council;

b. perbedaan pandang antara lembaga sertifikasi dengan nelayan ikan hias. Nelayan kurang merasakan manfaat sertifikasi ini. Harga ikan tetap sama ditingkat pengepul, sehingga tidak terjadi kenaikan pendapatan dari segi ekonominya.

Dampak sosial yang terjadi ini ditangkis oleh MAC Indonesia yang kini telah menjadi Yayasan Alam Indoneisa (LINI) yang berbasis di Denpasar, Bali dengan penjelasan sebagai berikut: Desa Les sebelumnya sudah melakukan tata cara penangkapan ikan hias laut yang ramah lingkungan. Sertifikasi adalah salah satu tahapan yang diharapkan dapat membantu mempromosikan upaya mereka untuk tingkat lebih global. Tidak hanya di Les, tetapi juga di desa lain, seperti Pejarakan (Kec. Gerokgak) dan Desa Tembok (Kec. Tejakula). Alasannya sama, yaitu mereka sudah melakukan cara tangkap yang ramah lingkungan dan mau untuk berubah ke arah yang lebih baik. Sertifikasi sendiri adalah sebuah proses untuk memperoleh sertifikat, dalam hal ini sertifikat telah memenuhi standar MAC. Sertifikat ini memang setiap dua tahun perlu dikaji kembali, apakah pihak-pihak yang sudah punya sertifikat masih konsisten dalam menjalankan prinsip-prinsip penangkapan dan penanganan yang lestari dan bertanggung jawab. Sertifikasi kembali akan dilakukan bila ada permintaan dari pihak produsen (eksportir yang link ke pengepul dan nelayan). MAC sebagai badan yang mengeluarkan standar membantu di tahap awal dan diharapkan akan dilanjutkan oleh para produsen ini.

2. Dampak ekonomi merupakan dampak dalam bidang yang dirasakan selama dua tahun pelaksanaan sertifikasi ramah lingkungan terhadap nelayan ikan hias:

a. selama dua tahun pelaksanaan sertifikasi nelayan diuntungkan dengan diberikannya jaring (alat tangkap ikan hias) secara cuma-cuma oleh MAC untuk pelaksanaan penangkapan yang ramah lingkungan dan sesuai standar;

b. harga jual ikan hasil tangkapan nelayan yang bersertifikasi seharusnya lebih tinggi dari pada nelayan tanpa sertifikasi. Hasil ikan tangkapan yang ramah lingkungan memilki mutu yang terjamin dari proses pengambilan ikannya. Namun, karena sistem pasar yang tidak mendukung membuat harga ikan dipasar tidak dibedakan. Sehingga tidak ada nilai tambah secara ekonomi bagi nelayan ikan hias;

c. ada kecenderungan terjadinya fenomena "Not Fair Trade" pada praktek perdagangan ikan ramah lingkungan di Indonesia. Ekolabel yang diberikan oleh MAC dijadikan sebuah instrumen pasar yang menguntungkan bagi salah satu pihak dari rantai perdagangan ikan hias. Seperti yang diketahui, ikan hasil tangkapan ramah lingkungan selain lebih sehat juga memiliki nilai tambah secara ekonomis. Nilai jual ikan di pasar internasional akan cenderung lebih tinggi, dengan margin yang menguntungkan pihak eksporti;

d. sebagian besar nelayan menyatakan bahwa tidak terjadi peningkatan pendapatan pada masa sertifikasi ini. Kondisi tempat tinggal dan status kepemilikan tempat tinggal nelayan tidak mengalami perubahan.

Sertifikasi ramah lingkungan dilakukan pada tahun 2006, lima tahun sejak masa transisi nelayan dari perikanan yang merusak menjadi perikanan yang ramah lingkungan. Kondisi lingkungan sudah berangsur membaik, sehingga sertifikasi yang hanya dua tahun tidak memiliki dampak terhadap lingkungan yang signifikan. Akan tetapi 50\% responden menyatakan bahwa terjadi peningkatan stok ikan selama masa sertifikasi ini, 35\% responden menyatakan bahwa hasil tangkapan sama besarnya dengan masa sebelum sertifikasi, dan sisa $15 \%$ responden adalah nelayan yang tingkat pengalamannya rendah (di bawah lima tahun). Nelayan yang memiliki tingkat pengalaman rendah, berarti nelayan yang belum pernah menggunkan potassium-sianida dalam menangkap ikan karena pada periode itu nelayan Desa Les telah beralih menggunakan jaring kembali.

PRL ikan hias hanya berlangsung selama dua tahun (2006-2008) yang ditutup dengan kolapsnya lembaga sertifikasi MAC Indonesia. Ketidakberlanjutan PRL berjalan di Indonesia disebabkan beberapa faktor, antara lain:

1. masalah kredibilitas program. Kredibilitas sebuah program ditentukan oleh tiga faktor utama, yakni legalitas, legitimasi, dan keformalan. PRL yang dilaksanakan di Desa Les mengalami masalah dalam hal ini. PRL ini merupakan program legal, namun legitimasi program ini mengalami masalah tersendiri. Oleh karena program ini merupakan introduksi dari 
program LSM internasional sehingga legitimasi program ini di Desa Les mengalami kendala. Demikian pula pada keformalan program, PRL bukan merupakan program formal dari pemerintah terkait;

2. ketidakberlanjutan lembaga sertifikasi. MAC sebagai lembaga sertifikasi mengalami kolaps pada tahun kedua pelaksanaan program. MAC tidak memenuhi aspek keberlanjutan dari sisi finansial, maupun keberlanjutan institusinya;

3. tidak berjalannya insentif yang diberikan kepada para pelaku pasar. PRL sebagai sebuah instrumen pasar seharusnya memberikan insentif kepada para pelaku untuk tetap menjalankan program ini.

\section{Kondisi Perikanan Ikan Hias Setelah Pelabelan Ramah Lingkungan (Ecolabelling)}

Keberlanjutan, menurut Bell (1998) esensinya adalah sebuah pertanyaan seberapa lama kita tetap melakukan ini. Praktek perikanan ramah lingkungan yang dilakukan oleh nelayan Desa Les merupakan bagian dari proses menuju perikanan yang berkelanjutan. Dalam Donda (2000) disebutkan untuk mewujudkan perikanan yang berkelanjutan dibutuhkan organisasi dan institusi untuk pengelolaan sumber daya alam. Organisasi merupakan sekumpulan orang yang memiliki kepentingan dan tujuan yang sama untuk sesuatu yang objektif yang melalui proses perubahan institusi (North, 1990 dalam Donda, 2000). Sedangakan institusi adalah kumpulan peraturan dalam suatu komunitas yang mengattur cara berinteraksi dan dipengaruhi oleh faktor sosial, ekonomi, dan politik. Institusi dapat berupa formal maupun informal tergantung situasi. Institusi yang bersifat formal biasanya menuliskan aturan-aturannya, sedangkan institusi informal tidak. Organisasi dan institusi inilah yang menguatkan pengelolaan perikanan yang bertujuan untuk mencapai perikanan yang berkelanjutan.

Galser et al. (2010) merumuskan beberapa instrumen yang seharusnya adalah dalam praktek perikanan yang berkelanjutan dalam hal konservasi alam. Instrumen perikanan berkelanjutan tersebut diadaptasi untuk mengidentifikasi praktek perikanan berkelanjutan pada program perikanan ramah lingkungan ikan hias di Desa Les:

1. keadilan distribusi, penting untuk memastikan siapa yang bertanggung jawab atas biaya dan yang memperoleh keuntungan dari wilayah yang dilindungi. Baik keuntungan materi maupun nonmateri. Keadilan distribusi pada praktek perikanan ramah lingkungan di Les, dari nelayan untuk nelayan. Nelayan yang bertanggung jawab atas laut, nelayan juga yang menikmati keuntungan dari laut yang dijaganya itu;

2. transparansi dan representatif, maksudnya untuk menghindari marginalisasi peraturan dan program ini dibangun, pemilihan pengurus, dan lainnya diurus secara inklusif. Pelaksanaannya transparan dan memenuhi unsur keterwakilan. Institusi yang memegang peran penting berjalannya program ini, Kelompok
Nelayan Ikan Hias Mina Bhakti Soansari dibangun secara musyawarah. Peraturan dibentuk juga melalui rembug warga nelayan, sehingga transparansi tetap terjaga;

3. budaya lokal, untuk memutuskan peraturan yang berkaitan dengan program perikanan ramah lingkungan, harus memperhatikan hal tabu, mitos, dan kepercayaan masyarakat setempat. Praktek perikanan ramah lingkungan di Desa Les ini berjalan dengan ritual-ritual keagamaan masyarakat Hindu Bali;

4. partisipasi aktif dari masyarakat khususnya pemangku kepentingan terkait. Partisipasi nelayan ikan hias Les dalam program ini telah mencapai tingkat yang cukup tinggi. Partisipasi terhadap pelaksanaan perikanan ramah lingkungan ada pada tingkat citizen control pada tangga partisipasi Arstein (1969);

5. mengaitkan pengetahuan lokal dan modern untuk pertimbangan pengambilan keputusan sehingga tidak berat sebelah. Pengetahuan modern dibawa oleh LSM untuk ditransfer kepada nelayan ikan hias yang memiliki pengetahuan lokal. Terjadikolaborasi pengetahuan yang membuat setiap keputusan dan peraturan yang dihasilkan dapat diterima dan dijalankan dengan baik;

6. peraturan lokal, tradisi masyarakat Hindu Bali yang tidak akan melakukan penangkapan pada hari-hari tertentu, misalnya pada hari raya besar umat Hindu Bali,seperti Galungan, Kuningan, dan Nyepi. Peraturan lokal ini harus dihormati.

Nelayan Desa Les dapat dikategorikan sebagi sebuah komunitas, karena tinggal di dalam satu wialayah teritori, memiliki sturktur sosial yang hampir sama, dan memiliki kepentingan dan norma yang sama dalam pemanfaatan sumber daya alam laut. Pengelolaan sumber daya berbasis masyarakat adalah pengelolaan yang menempatkan masyarakat sebagai pengelola sumber daya alam. Adapun prinsip-prinsip pengelolaan sumber daya berbasis masyarakat adalah:

1. karakteristik sumber daya alam, kelompok yang akan mengelolanya, batas wilayah, dan aturan yang jelas (Ostrom (1990) dalam Amirtage (2005); Ruddle (1999)). Sumber daya alam yang dimiliki oleh masyarakat nelayan desa Les adalah laut. Pengelolaan laut ini adalah masyarakat nelayan ikan hias yang tinggal di pesisir Desa Les;

2. anggota komunitas memiliki akses yang sama untuk memperkecil timbulnya konflik (Ostrom (1990) dalam Amirtage (2005); Ruddle (1999)). Otoritas lain yang diluar komunitas dapat mengatur dan memberikan saran kepada institusi;

3. organisasi pengelolaan (Ruddle, 1999). Organisasi pengelolaan adalah institusi yang dibentuk komunitas sendiri untuk memantau perkembangan dan sebagai wadah bertukar pikiran untuk kemajuan bersama. Dalam hal ini institusi yang dimaksud adalah kelompok nelayan ikna hias Mina Bhakti Soansari. Di dalam institusi ini ada mekanisme pengambilan 
keputusan, juga ada kepengurusannya, dibentuk oleh masyarkat nelayan sediri dengan pengutan oleh LSM pendamping;

4. pegawasan (Ostrom (1990) dalam Amirtage (2005); Ruddle (1999)). Merupakan sebuah aspek yang penting untuk menjaga keberlangsungan program. Monitoring juga dilakukan terhadap lingkungan, institusi, serta sebagai sarana untuk resolusi konflik bila ada. Dilakukan oleh masyarakat secara sukarela. Pengawas laut biasa disebut sebagai pecalang laot oleh masyarakat Bali. Di Desa Les tidak terdapat pecalang laot sehingga pegawasan laut dilakukan bersama-sama oleh para nelayan;

5. sanksi (Ruddle, 1999). Sanksi merupakan salah satu aspek yang dapat menguatkan pelaksanaan pengelolaan berbasis masyarakat. Sanksi juga merupakan indikator berjalan tidaknya suatu aturan. Pada pelaksanaan pengelolaan sumber daya laut Les, sanksi yang diterapkan ada dua macam. Sanksi hukum berdasarkan hukum yang berlaku di negara Indonesia dan sanksi adat yang termuat dalam awig-awig Les.

Pengelolaan sumber daya berbasis masyarakat penting karena mempengaruhi keseimbangan ekonomi, sosial, dan ekologi. Ruddle (1999) dan Berkes (1989) dalam Adhuri (2004) menyatakan dimensi yang terpenting adalah:

1. jaminan mata pencaharian, dengan memastikan setiap anggota komunitas nelayan ikan hias dapat memenuhi kebutuhan dasarnya dengen memanfaatkan hak akses atas sumber daya laut. Sebagai aktor utama, nelayan ikan hias harus memnuhi unsur ini untuk tetap bertahan hidup;

2. kesamaan akses terhadap sumber daya. Setiap anggota komunitas nelayan ikan hias memilki akses yang sama terhadap sumber daya laut. Tidak ada nelayan yang memiliki eksklusifitas dalam hal ini;

3. reorientasi pada keberlanjutan ekologi yang mengsinkronisasikan ritual dengan siklus alam. Selain dengan menerapkan pengatahuan yang modern dan lokal, keberlanjutan ekologi juga memperhatikan tradisi dan siklus alam Les.

Pengelolaan sumber daya berbasis masyarakat yang dilakukan oleh masyarakat nelayan Les diinisiasikan oleh LSM. Dilakukan untuk merehabilitasi ekologi Laut Les, yang kemudian dikuatkan dengan pembentukan institusi kelompok nelayan. Pengembangan kapasistas masyarakat lokal dilakukan dengan sosialisasi dan internalisasi nilainilai lokal untuk pengelolaan sumber daya alam, dan dengan mereinpretasi nilai-nilai agama Hindu Bali. Pada skala regulatif, dilakukan pengembangan kapasitas organisasi masyarakat nelayan, penguatan jaringan nelayan dengan berbagai pihak untuk membuka wawasan nelayan. Kemudian melalui pendidikan lingkungan hidup, pengelolaan sumber daya alam, LSM menyadarkan nelayan ikan hias pentingnya praktek perikanan yang ramah lingkungan.
Sanksi merupakan salah satu aspek yang dapat menguatkan pelaksanaan pengelolaan berbasis masyarakat. Sanksi juga merupakan indikator berjalan tidaknya suatu aturan. Pada pelaksanaan pengelolaan sumber daya laut Les, sanksi yang diterapkan ada dua macam. Sanksi hukum berdasarkan hukum yang berlaku di negara Indonesia dan sanksi adat yang termuat dalam awig-awig Les. Berdasar pada wawancara mendalam mengenai awig-awig Les, peraturan ini sempat mengalami masa diabaikan. Penggunaan sianida untuk menangkap ikan hias merupakan pelanggaran terhadap sistem awig-awig yang berkembang di Desa Les. Namun saat itu, hampir selruh nelayan ikan hias menangkap dengan menggunakna sianida. Tuntutan ekonomi kemudian memudarkan nilai-nilai yang telah dibangun sebelemnya. Kerusakan laut yang terjadi di Les bagi masyarakat merupakan sanksi besar yang harus diterima masyarakat akibat pelanggaran awig-awig yang berlangsung hingga bertahun-tahun. Masyarakat setempat menganalogikan peristiwa ini sebagai kemarahan Tuhan.

Revitalisasi awig-awig menjadi topik hangat yang diangkat kembali saat pengelolaan laut Les mulai mengarah kepada perikanan yang ramah lingkungan. Ada urgensi yang menguat untuk merevitalisasi sistem awig-awig ini. Namun, revitalisasi ini belum terlaksana. Untuk sementara waktu, sistem awig-awig Desa Les masih sama dengan yang dulu. Hanya saja sistem ini sudah mulai diterapkan kembali bagi yang melanggar.

\section{KESIMPULAN DAN SARAN}

PRL ikan hias dan nelayan ikan hias di Desa Les, Bali memiliki sebuah hubungan tak langsung yang mempengaruhi. Perubahan praktek perikanan di daerah ini dari menggunakan potassium dan sianida yang merupakan bahan perusak alam terutama terumbu karang dimulai sejak tahun 2000 melalui pendekatan oleh Yayasan Bahtera Nusantara sebagai LSM lokal dan Telapak Indonesia. Perubahan bersifat mendasar, dari cara menangkap ikan, alat yang digunakan, sistem penangkapan ikan, hingga penanganan pascatangkap pun berubah menjadi lebih memperhatikan aspek lingkungan. Pensertifikasian nelayan, pengepul, dan eksportir mulai dilaksakan pada tahun 2006 oleh Marine Aquarium Council hingga tahun 2008 lembaga ini kolaps karena minimnya dana operasional. Sertifikasi oleh MAC hanya berlaku selama dua tahun di Les. Akan tetapi, tanpa PRL ikan hias Les tetap bisa menembus perdagangan ikan hias internasional.

Secara umum, PRL di desa Les hanya berjalan selama dua tahun. Dari sisi ekonomi, PRL belum mampu menaikkan harga jual ikan ditingkat pengepul, sehingga tidak terjadi peningkatan pendapatan yang signifikan dari perubahan pola tangkap ini. Kondisi tempat tinggal, pendapatan sehari-hari, tingkat pendidikan rata-rata keluarga nelayan tidak mengalami perubahan yang berarti. Harga ikan yang telah disertifikasi di tingkat pengepul cenderung sama dengan harga ikan yang tidak disertifikasi. Hal ini tidak 
sesuai dengan visi awal PRL yang ingin meningkatkan harga ikan hias. Dari sisi sosial, nelayan ikan hias yang telah disertifikasi tidak mengalami perubahan pada posisi sosial. Pada sisi ekologi, perubahan lingkungan telah dilakukan oleh nelayan dan LSM sebelum PRL masuk di Les. Dibangun Kelompok Nelayan Ikan Hias Mina Bhakti Soansari sebagai wadah bagi nelayan untuk saling bertukar informasi dan berbagi pengalaman. Tingkat pendidikan nelayan tidak mempengaruhi signifikan akan keikutsertaan nelayan dalam kelompok, begitu juga tingkat pengalaman kerja. Baik yang berpendidikan rendah maupun tinggi, serta berpengalaman atau belum berpengalaman memiliki keterikatan yang tinggi dalam kelompok nelayan. Oleh karena ada motif lain yang lebih kuat dari sekedar pendidikan dan pengelaman kerja, yaitu kesadaran nelayan yang tinggi dalam melaksanakan perikanan yang ramah lingkungan.

Ekologi laut Les yang sudah mulai membaik menunjukkan kestabilan keberlimpahan dan keanekaragaman ikan. Dengan demikian meski harga ikan di tingkat pengepul tidak mengalami kenaikan, namun kestabilan hasil tangkapan membantu nelayan mencukupi kebuthan sehari-harinya. Dengan beralih menjadi nelayan yang ramah lingkungan nelayan menjadi lebih aman dan memilki nilai sosial yang lebih baik. Perlu digarisbawahi bahwa perubahan lingkungan ini telah berlangsung sebelum PRL diterapkan. Pada pelaksanaan PRL selama dua tahun ini, cenderung tidak menunjukkan perubahan. Adapun saran yang dapat diberikan dari hasil penelitian ini, adalah:

1. perhatian pemerintah dalam hal ini Kementrian Kelautan dan Perikanan dengan memberikan penghargaan mengingat perubahan praktek yang lebih baik yang dilakukan oleh nelayan ikan hias desa Les. Pemerintah juga diharapkan dapat membantu nelayan mengatasi kendala yang terjadi di lapang terutama isu pengkaplingan luat, yang terjadi tidak hanya di lokasi penelitian. Semoga akan ada kebijakan yang dapat membantu nelayan;

2. pengembangan masyarakat nelayan. Selama ini belum ada program pengembangan masyarakat yang membantu para keluarga nelayan untuk menjadi lebih baik dari sisi sosial-ekonomi terutama dalam bidang pendidikan;

3. penelitian lebih lanjut mengenai ekologi politik ekolabeling, serta penelitian lintas disiplin ilmu untuk melihat besar perubahan ekologi yag telah terjadi di Desa Les dan bagaimana mempertahankannya agar tetap berkelanjutan.

\section{DAFTAR PUSTAKA}

Adiwibowo, S (Editor). 2007. Ekologi Manusia. Bogor: Institut Pertanian Bogor.

Adhuri, Dedi Supriadi. 2004. "The Incident In Dullah Laut: Marine Tenure and the Politics of Village Leadership in Maluku, Eastern Indonesia”.
Agrawal, Arun dan Calrk Gibson. 1999. "Enchantment and Disenchantment: The Role of Community in Natural Resource Conservation". World Development Vol. 27, No. 4, pp. 629 $\pm 649,1999$.

Alencastro, Liliana A, et al. 2005. 'Hobbyists' Preferences For Marine Ornamental Fish: a Discrete Choice Analysis of Ecolabeling and Selected Product Attributes". SPC Live Reef Fish Information Bulletin \#15. Tahun 2005.

Arnstein, Sherry R. 1969. A Ladder Warga Negara Partisipasi. [Internet]. [Dikutip 26 Agustus 2011]. Dapat diunduh dari: http://lithgow-schmidt.dk/ sherry-arnstein/ladder-of-citizen-participation. html.

Amirtage, Derek. 2005. "Adaptive Capacity and Community-Based Natural Resource Management”. Forum DOI: 10.1007/s00267-0040076-z.Tahun 2005.

Bell, Micheal Mayerfeld. 1998. "An Invitation to Environmental Sociology". United Kingdom: Wiley-Blackwell.

Bryant, Raymond L dan Sinead Bailey. 2005. "Third World Political Ecology". New York: Routledge.

FAO Fisheries Departement. 2007. "FAO Guidelines for Ecolabeling of Fish and Fisheries Products form Marine Capture Fisheries". Paris: FAO.

Forsyth, Tim. 2008." Political Ecology and The Epistemology of Social Justice". Journals of Geoforum 39 (2008) 756-764. Tahun 2008.

Fox, Helen, Peter J. Mous, et.al. 2005. "Experimental Assesment of Coral Reef Rehabilitation Following Blast Fishing". Journal of Conservation Biology, Volume 19, No. 1 Ferbuari 2005.

Frey, James Barcklay. 2011. "Single- and Double-loop Learning in the Commons Two case studies from Malawi". Tidak dipublikasikan.

Gardiner, P.R. dan K. Kuperean Visnawathan. 2004. "Ecolabeling and Fisheries Management". World Fish Center Studies and Reviews 27, 44. Tahun 2004

Glaser, Marion, et.al. 2010. "Whose sustainability? Topdown participation and emergent rules in marine protected area management in Indonesia". Marine Policy 34 (2010) 1215-1225.

Gudmundsson, Eyjolfur dan Cathy Wessel. 2000. "Ecolabelling Seafood for Sustainable Production: Implication for Fisheries Management" Journals of Marine Resource Economics, Volume 15, pp. 97113. Tahun 2000.

Kartodiharjo, Hariadi dan Hira Jamthani. 2006. Politik Lingkungan dan Kekuasaan di Indonesia. 
Jakarta: Ford Foundation, Equinox. Kristanto, P. 2004. Ekologi Industri. Yogyakarta: Andi Yogyakarta.

LINI. 2008. Laporan Pengelolaan Perikanan Kecamatan Tejakula 2006. Reef Check Foundation.

Molyneaux, Paul. 2008. "Certifiying the Certificate". The Triannual Journal of The International Collective in Support of Fishworkers, No 51. November 2008.

Mugniesyah, Siti Sugiah. 2006. Penyuluhan Pertanian: Bahan Ajar Kuliah Ilmu Penyuluhan. Bogor: tidak dipublikasikan.

Mungkung, et.al. 2006. "Potentials and Limitations of Life Cycle Assessment in Setting Ecolabelling Criteria: A Case Study of Thai Shrimp Aquaculture Product". Journal of Thai Shrimp Aquaculture Product. Int J LCA 11 (1) 55 - 59. Tahun 2006.

Nunes, Paulo dan Yohanes E. Ryanto. 2005. "Information as a regulatory instrument to price biodiversity benefits: certification and ecolabeling policy practices". Journals of Biodiversity and Conservation (2005) 14: 2009-202. Tahun 2005.

Ostorm, Ellinor dan Charlotte Hess. 2007. "Private and Common Property Rights". Workshop mengenai Political Theory and Policy Analysis, Indiana University. W07-25. Tahun 2007.

Ostorm, Elinor, et.al. 1999. "Revisiting the Commons: Local Lessons, Global Challenges". Science 284, 278 (1999).

Potts, Tavis dan Marcus Haward. 2006. "International Trade, Eco-Labelling, and Sustainable Fisheries Recent Issues, Concepts and Practices". Environment, Development and Sustainability (2007) 9: 91-106. Tahun 2006.

Putra, S. dan A. Cottre. 2000. "Conflicts of coastal management in North Sulawesi”. Proceedings 9th International Coral Reef Symposium, Bali, Indonesia 23-27 October 2000, Vol. 2.

Rachmadaran, A. 2010. "Ecolabeling and Green Certification for Effective Fisheries Management - An Analysis". World Academy of Science, Engineering and Technology 65. Tahun 2010.

Sainsbury, Keith. 2010. "Review of Ecolabelling Schemes for Fish and Fisheries Products from Capture Fisheries". Roma, Itali: FAO.

Satria, Arif. 2009. Ekologi Politik Nelayan. Yogyakarta: LKis.

2009. Pesisir dan Laut Untuk Rakyat. Bogor: IPB Press.
2006. "Politics of marine conservation area in Indonesia: from a centralised to a decentralised system". Int. J. Environment and Sustainable Development, Vol. 5, No. 3, 2006.

2006. "Decentralization of Property Right in Marine Fisheries: Indonesia Perspective". Tidak dipublikasikan.

Pengantar Sosiologi Masyarakat Pesisir. Jakarta: Cesindo. Sinclair, M. dan G. Valdimirsson. 2003. Responsible Fisheries in The Marine Ecosystem. Roma, Italy: CABI Publishing.

Silalahi, M.D. 2001. Hukum Lingkungan dalam Sistem Penegakan Hukum Lingkungan Indonesia. Bandung: PT. Alumni.

Sugandhy, A dan R. Hakim. 2009. Prinsip Dasar Kebijakan Pembangunan Berkelanjutan Berwawasan Lingkungan. Jakarta: Bumi Aksara.

Sukada, Sonny dkk. 2007.Membumikan Bisnis Berkelanjutan. Jakarta: Indonesia Business Links.

Suwarsono dan Alvin Y. SO. 2006. Perubahan Sosial dan Pembangunan. Jakarta: LP3ES.

Sztompka, Piotr. 1994. "The Sociology of Social Changes". United Kingdom Wiley-Blackwell.

Robbins, Paul. 2004. Political Ecology. United Kingdom: Blackwell Publishing. Wahyuni, E.S dan Muljono, P. 2009. Metode Penelitian Sosial. Bogor: Departemen Sains Komunikasi dan Pengembangan Masyarakat, Fakultas Ekologi Manusia, IPB.

Ward, Trevor, dan Bruce Phillpis. 2008. Seafood Ecolabelling: Principle and Practice. United Kingdom: Blackwell Pub. 